\title{
Revision of the endemic giant fire millipedes of Madagascar, genus Aphistogoniulus (Diplopoda: Spirobolida: Pachybolidae)
}

\author{
Thomas Wesener ${ }^{*}{ }^{1,4}$, Henrik Enghoff ${ }^{2}$, Richard L. Hoffman ${ }^{3}$, \\ J. Wolfgang Wägele ${ }^{1} \&$ Petra Sierwald $^{4}$ \\ ${ }^{1}$ Zoologisches Forschungsmuseum Alexander Koenig, Museumsmeile Bonn, \\ Adenauerallee 160, D-53113 Bonn, Germany. \\ ${ }^{2}$ Natural History Museum of Denmark, Universitetsparken 15, DK-2100 Copenhagen Ø, Denmark. \\ ${ }^{3}$ Virginia Museum of Natural History, 21 Starling Avenue, Martinsville, VA 24112, U.S.A. \\ ${ }^{4}$ Field Museum of Natural History, 1400 S. Lake Shore Drive, Chicago, IL 60605, U.S.A. \\ *Corresponding author. E-mail: thomas.wesener@rub.de
}

\begin{abstract}
The Malagasy fire millipede genus Aphistogoniulus (Silvestri, 1897) is revised. All previously described species, A. cowani (Butler, 1882), A. erythrocephalus (Pocock, 1893), A. hova (de Saussure \& Zehntner, 1897), A. corallipes (de Saussure \& Zehntner, 1902), A. sakalava (de Saussure \& Zehntner, 1897), are redescribed. Four new synonyms are confirmed: Aphistogoniulus sanguinemaculatus (Silvestri, 1897) new synonym of $A$. cowani, A. quadridentatus (Attems, 1910) new synonym of $A$. erythrocephalus, A. polleni Jeekel, 1971 and $A$. brolemanni Jeekel, 1971 new synonyms of $A$. hova. Scanning electron microscopy is utilized to investigate the sexual differences on the antenna, mandible and gnathochilarium in $A$. cowani. The intraspecific variation of the taxonomic characters within and between different populations of $A$. erythrocephalus (Pocock, 1893) is examined. Five new species (A. sanguineus Wesener, n. sp., A. infernalis Wesener, n. sp., A. diabolicus Wesener, n. sp., A. aridus Wesener, n. sp., A. vampyrus Wesener, n. sp.) are described, including the first records of the genus from the Malagasy spiny forest and azonal Western deciduous forest ecosystem. A key to Aphistogoniulus species is provided.
\end{abstract}

\section{Key words}

Aphistogoniulus, Madagascar, microendemism, intraspecific variation, biogeography

\section{Introduction}

The large fire millipedes, genus Aphistogoniulus, are one of the most remarkable elements of the highly endemic macro-invertebrate fauna on Madagascar. Members fea- 
ture a striking blood-red/pitch-black aposematic color pattern, in some species combined with golden legs (Figs 1A-H, 7A-E). The varicolored pattern and a large size of up to $180 \mathrm{~mm}$ have contributed to the strong demand for Aphistogoniulus by pet owners in Europe and North America. Like most millipedes from Madagascar (Wesener \& Sierwald 2005, Wesener et al. 2008, Wesener \& Wägele 2008), only a few species of Aphistogoniulus were well enough described and readily identifiable with the available literature (Jeekel 1971). Especially the identities of the oldest three names associated with the fire millipedes, Spirostreptus cowani Butler, 1882, Spirobolus erythrocephalus Pocock, 1893, and Trigoniulus sanguinemaculatus Silvestri, 1897, were ambiguous. Further obstacles impeding progress in Aphistogoniulus taxonomy were names introduced by de Saussure \& Zehntner $(1897,1902)$, since their type series obviously included several species; holotypes were not designated.

Inventory work conducted on Madagascar mainly by Brian Fisher from the California Academy of Sciences and Steven Goodman from the Field Museum of Natural History, Chicago, yielded a large number of fire millipede specimens, which made this revision of the genus Aphistogoniulus possible. The revision includes the description of five new species, the selection of lectotypes and the addition of more detailed data on the distribution of the Aphistogoniulus species on Madagascar. The knowledge of the exact distribution of fire millipede species is especially important for conservation planning, since Madagascar represents one of the World's most endangered centers of endemism (Myers et al. 2000, Lowry et al. 2001). Numerous specimens of $A$. erythrocephalus from six localities and different elevations were studied to evaluate the intraspecific variation of taxonomically important characters in Aphistogoniulus.

\section{Material and methods}

Abbreviations:

BLF Collection code for Madagascar sample at the CAS

BM "British Museum", collection label for specimens stored at the Natural History Museum London, U.K.

CAS California Academy of Sciences, San Francisco

FMMC Specimen code for millipede samples at the FMNH

FMNH Field Museum of Natural History, Chicago

MHNG Musée d'Histoire Naturelle, Genève

MNHN Muséum d'Histoire Naturelle, Paris

ZFMK Zoologisches Forschungsmuseum Alexander Koenig, Bonn, Germany

ZMUC Zoological Museum, University of Copenhagen

ZMH Zoologisches Museum, Universität Hamburg, Germany

ZSM Zoologische Staatssammlung München, Germany

Collecting: specimens deposited at CAS and FMNH were mainly taken by pitfall trapping or hand collecting. During a trip by TW to Southeastern Madagascar in May to 
June 2007, only hand collecting was utilized (Mesibov et al. 1995). Six, eight and eight local field assistants and researchers spent five, five and four hours specially searching for millipedes in PN Manantantely, Sainte Luce and the Andohahela Isaka-Ivondro corridor, respectively. Specimens were killed by freezing and later preserved in $75 \%$ ethanol. All specimens with a CAS label are stored in the collections of the California Academy of Sciences, all with a FMMC label at the Field Museum of Natural History.

Dissections and illustrations: pencil drawings were produced using a standard camera lucida. Photographic images were taken with a Microptics-Imaging-System (based at the FMNH). Additional images were taken with a Leica ${ }^{\circ} \mathrm{Z} 6$ imaging system (based at the ZFMK). Final images were assembled from 6-10 source images taken at different focal lengths using the software package Auto-Montage. For scanning electron microscopy, samples were cleaned and dehydrated in an ethanol series $(80 \%, 90 \%, 95 \%$ and two times in $100 \%)$ and air-dried overnight. The samples were then mounted on aluminum stubs and coated with gold in a sputter coater for 240 seconds. SEM micrographs were taken using a Zeiss (Leo) EVO SEM, based at the FMNH. All images were later modified using Adobe Photoshop CS2 and assembled into plates using Adobe Illustrator CS2.

\section{Results}

Genus Aphistogoniulus Silvestri, 1897

Aphistogoniulus Silvestri, 1897b: 651. Type species: Trigoniulus sanguinemaculatus Silvestri, 1897, by original designation. T. sanguinemaculatus is a synonym of $A$. cowani (Butler, 1882), new synonymy.

Mystalides Attems, 1910: 94. Type species: M. quadridentatus Attems, 1910, a synonym of $A$. erythrocephalus (Pocock, 1893), new synonymy. Generic synonymy by Jeekel 1971: 33 .

We agree with the synonymy of Mystalides in Aphistogoniulus because the slight differences in the posterior gonopods between $A$. cowani and A. erythrocephalus do not warrant a different genus.

\section{Valid species included:}

A. erythrocephalus (Pocock, 1893)

A. hova (de Saussure \& Zehntner, 1897)

A. sakalava (de Saussure \& Zehntner, 1897)

A. corallipes (de Saussure \& Zehntner, 1902)

A. sanguineus n. sp.

A. infernalis n. sp.

A. diabolicus n. sp.

A. aridus n. sp.

A. vampyrus n. sp. 
Taxonomic position: the presence of a sclerotized sternite connecting the posterior gonopods and the complete reduction of the anterior gonopodal apodemes place the genus Aphistogoniulus in the family Pachybolidae, suborder Trigoniulidea.

Diagnosis: large-bodied pachybolids, of elongated and slender appearance, 80-180 $\mathrm{mm}$ long. Males (7.5-11.5 mm wide) more slender than females (up to $14 \mathrm{~mm}$ wide). Number of body rings in mature individuals varies between 48 and 62. Always with aposematic blood-red/pitch-black color pattern, with red or golden legs (Figs 7A-E). Males with tarsal pads starting on third leg (Fig. 11A). No coxal processes on male legs 3-7 (Fig. 17A). Preanal ring apically never extending posteriorly beyond well-rounded anal valves (Fig. 1B, D). Anterior gonopod sternite prominent, generally of triangular appearance (Figs 9A-C). Coxite in oral view elongated mesally into a long process ( $c p$ ), process basally wide, tapering towards tip (Fig. 2A). Tip extending as long as or longer than telopodite. Coxite $(C x)$ with shallow mesal excavation enveloping the telopodite basally and laterally (Fig. 2A). Telopodite elongated into moderately swollen, mesad appendage (Fig. 2A, $a p p$ ). Appendage laterally always with large, moderately retrorse, triangular process (Figs 2A, 8A, rp). Posterior gonopods connected by membrane and sclerotized sternite. Coxite elongated into long and slender stem. Telopodite only loosely connected with coxite via membrane and sperm channel. Telopodite basally split into a main branch $(m b)$ and a basal branch $(b b)$; both variable in length, size and shape (compare Figs 2C, 12A, 15B). Telopodite main branch slightly and evenly bent inwards, uniquely identified by its mesal position. Basal branch often slightly bent outwards, almost touching tip of main branch; telopodite branches forming an 'O' or an almost closed 'C'. Main branch always with, basal branch always without sperm channel. Aphistogoniulus is characterized among Spirobolida genera by the uniquely-shaped posterior gonopods with a mobile, loosely connected telopodite at the apex. Currently, no close relative of Aphistogoniulus is known, but two undescribed genera from Madagascar might be related.

Description: Color: always with aposematic color pattern consisting of blood-red, pitch-black and sometimes gold. Head at least frontally, and antenna blood-red. Posterior part of telson always blood-red. Legs golden or blood-red. Metazonites dorsolaterally with a species-specific blood-red pattern. Body rings on dorsal side often with a pitch-black line, sometimes a row of large black spots, at least metazonites of body rings dorsally pitch-black. Body rings laterally pitch-black. If blood-red area extends below ozopore openings, then openings marked by large black spot (Fig. 7A).

Head: usually with 35-40 ocelli (Figs 1A, C, E-H). Labrum with 3-4 irregular teeth and row of $8+8$ stout, marginal setae. Antenna extending posteriorly to body ring 3-7, length species-specific (Figs 1A, C, E-H). Relative length of antennomeres: $1<<2>>3=4=5=6$ (Fig. 10A); terminal antennomere with four large sensory cones located together in a membranous area (Figs 3A, D, E, F). Antennomeres 5 and 6 lateroapically with field of 4-8 (Fig. 3B) and 2-6 rows (Fig. 3D) of sensilla basiconica.

Gnathochilarium: usual shape of spirobolidans (Fig. 4A). Lamellae linguales each with two setae, one behind the other (Fig. 4B). Stipites laterally slightly excavated, each with three apical setae. Mentum and stipites with several transverse ridges in basal half (Fig. 4A). Palpi of gnathochilarium with numerous sensilla. Hypopharyngeal crest 


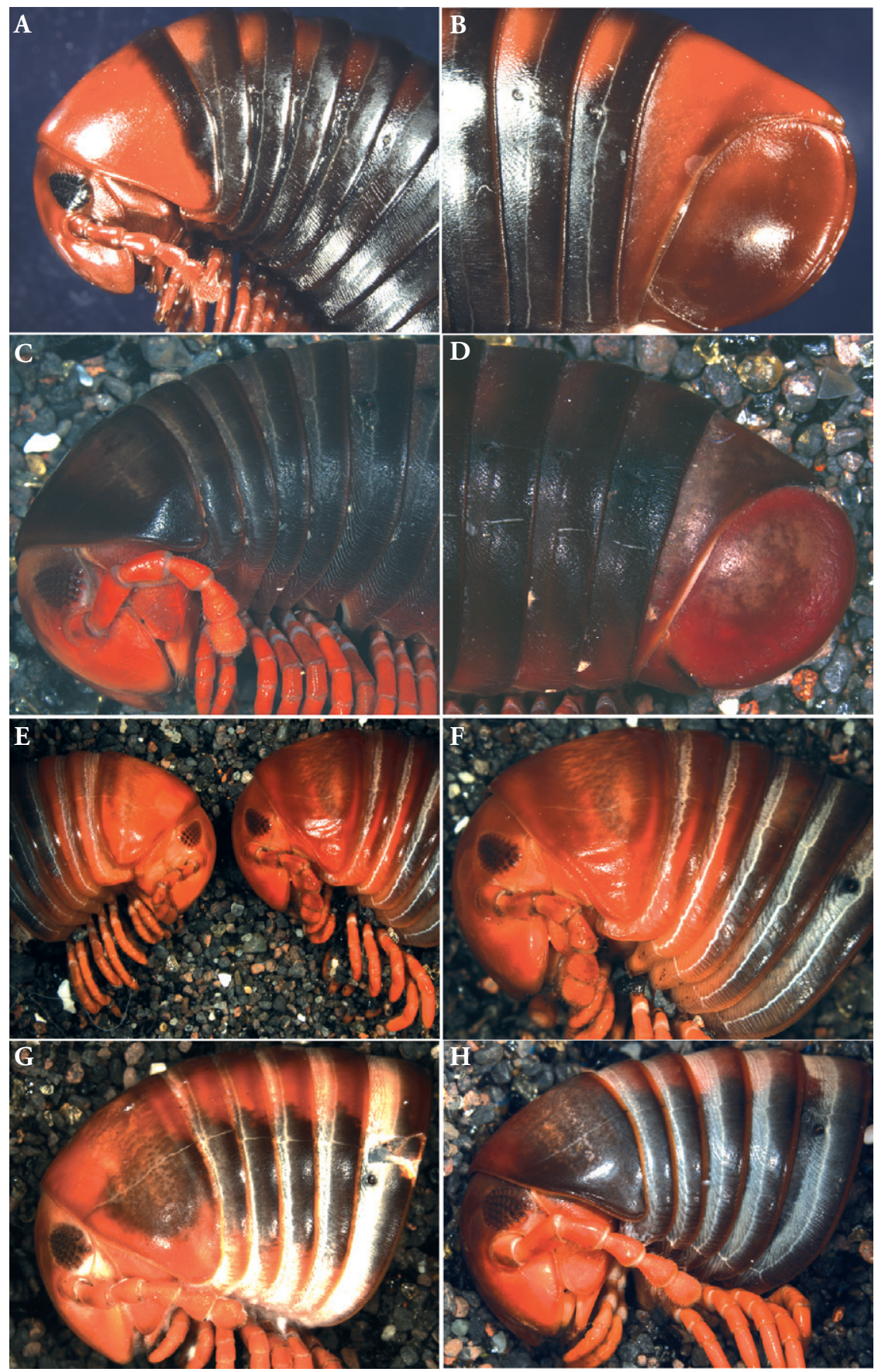

Figure 1. A: A. cowani, female head, lateral view (CAS no number); B: A. cowani, male telson, lateral view (CAS no number); C: $A$. corallipes, male head, lateral view (FMMC); D: A. corallipes, male telson (FMMC); E: $A$. sanguineus n. sp., left, female paratype, right, male holotype (CAS BLF 7024); F: $A$. sanguineus n. sp., male holotype (CAS BLF 7024); G: A. aridus n. sp., male holotype (CAS BLF 5241); H: $A$. vampyrus n. sp., male holotype (FMMC). Images not to scale. 
with field of spine-like structures (Fig. 4D). Central pads of endochilarium divided by a groove and a ridge into two separate distinct regions; a group of circa 12-14 sensilla in circular arrangement located in the region close to the endochilarium (Figs 4D, E). Medial palps each with a large group of sensilla, located towards hypopharyngeal crest and field of spines (Fig. 4D, F); these sensilla (only studied in A. cowani and A. erythrocephalus) with internal siphon (Fig. 4G)

Mandible (only studied in A. cowani and A. erythrocephalus): slim and elongated (Figs 5A, 10B). External tooth simple, rounded; inner tooth with four cusps (Figs 5B, 10C), laterally an additional, isolated, simple tooth (putative synapomorphy of Spirobolida, Sierwald \& Bond 2007). Number of pectinate lamellae 4-6. Mesal margin of pectinate area with circa four rows of small, slender spines, a row of spines continued along mesal margin of otherwise smooth intermediate area. Molar plate long and slim, with $>8$ transverse furrows.

Collum: lateral margins well-rounded, not reaching tips of second body ring, surface smooth (Fig. 1A).

Body rings divided by sutures in three transverse zones, pro-, meso- and metazona. Ozopores located on mesozona, starting on segment 6, located close to, but not touching suture between meso- and metazona (Fig. 1B). Surface of body rings with weak longitudinal impressions in ventral half of meso- and metazona.

Anal valves smooth, with neither lips nor micropunctation, nor grooves, nor setae (Figs 1B, D). Preanal ring not protruding posteriorly beyond anal valves. Subanal scale inconspicuous.

In first and second pair of legs, coxa elongated and fused with sternite. First pair of legs larger than second. First with one pair of spines located apically each on prefemur, femur, postfemur and tibia. Tarsus ventrally with three pairs of spines. Second leg pair with one pair of spines apically each on prefemur, femur and postfemur, tibia apically with three spines. Tarsus ventrally with three or four pairs of spines. Legs three and beyond elongated, clearly longer than width of body rings in both sexes, but legs longer in relation to body diameter in males than in females. Prefemur, femur, postfemur and tibia apically with one spine each. Tarsi in females and juveniles with one large and one smaller ventral spine, in males with a pair of smaller ventral spines (Fig. 11B). Leg pair three and beyond with rectangular coxa (Fig. 11A). Prefemur long, laterally slightly excavated (Fig. 11A).

Male sexual characters: coxae of male legs 3-7 not modified. Seventh body ring of males only slightly larger than other body rings, gonopods completely retractable. Male legs three and beyond with tarsal pad; large tarsal pad not extending beyond the claw (Fig. 11A).

Anterior gonopods: sternite more or less triangular, basally broad, width at least slightly tapering towards well-rounded tip (Figs 9A-C). Coxite in oral view mesally elongated into basally wide, apically strongly tapering process (Fig. 2A, $c p$ ). Process as long as or longer than telopodite (Figs 9A-C). Telopodite basally enfolded by coxite. Mesal margin of telopodite always with erect, wide and knob-like appendage (Fig. 2A, $a p p$ ). Appendage laterally always with more or less sharp, retrorse process (Fig. 2A, $r p$ ).

Posterior gonopods connected by broadly triangular sclerotized sternite (Fig. 14B). Coxite strongly elongated, with long "stem", basally with single groove and finger- 
shaped process (Fig. 2C, $f s-p$ ). Telopodite only loosely connected with coxite by membrane and via sperm channel. Telopodite basally divided into two branches. Tips of both branches juxtaposed to one another, forming an 'O' or an almost closed ' $\mathrm{C}$ ' (Fig. 2B). Basal branch of telopodite usually bent inwards, main branch located mesally (Fig. 16C, D). The opening of the ' $\mathrm{C}$ ' therefore orientated laterally. Sperm channel running at mesal margin of coxite through telopodite main branch (Fig. 8B).

Female characters: antennae and legs as long as in males, but legs appear shorter because of larger body diameter. Vulvae located in pouches behind coxosternite of second legs, consisting of two plates plus small, poorly sclerotized operculum at base.

Sexual dimorphism: in all species of Aphistogoniulus the width of the body rings in females is 20-30 \% larger than in males. Males are usually $10 \%$ shorter than the largest females. Mature females are often present in two size categories, the smallest mature females being as long as the males. This is interpreted as an indication that females can molt (and grow) after reaching sexual maturity, while males cannot. Legs and antenna are of equal length in both sexes. Males and females possess the same number of sensory cones on the antenna (apical cones and rows of sensilla basiconica) and gnathochilarium (only checked in A. cowani). Color is similar in both sexes.

Ecology and behavior: with one exception (A. corallipes, which was found inside the leaf litter), all species of Aphistogoniulus were found on the surface, often climbing on vegetation, or resting in epiphytes. Male specimens of $A$. corallipes and $A$. infernalis n. sp. were found riding on females. In June, each female was attached to a male.

Distribution: lowland and montane rainforests of Madagascar. However, A. sanguineus n. sp. is endemic to an azonal forest in western central Madagascar and $A$. aridus $\mathbf{n}$. sp. is endemic to the southern spiny forest.

\section{Key to the Aphistogoniulus species:}

1a Mesozona of body rings dorsally completely blood-red, metazona completely pitch-black, legs red, 47 body rings (Fig. 7C), smaller than $100 \mathrm{~mm}$. Recorded circa $10 \mathrm{~km} \mathrm{~W}$ of Perinet ........................................ Aphistogoniulus sakalava

1b Combination of characters not as above................................................2

2a Posterior gonopod telopodite, basal branch shorter than main branch (Fig. 2C)... 3

2b Posterior gonopod telopodite, basal branch longer than main branch (Fig. 16C)

3a Posterior gonopod telopodite main branch mesally with a strongly developed membranous fringe, elongated into short, conspicuous process (Figs 2B, D, 14C) .......4

3b Posterior gonopod telopodite main branch only apically and laterally with membranous fringes. Fringes never elongated into process (Figs 8B, 11C) ....5

4a Posterior gonopod, mesal membranous fringe strongly developed into erect process (Fig. 2B). Telopodite only slightly becoming thicker from beginning of fringe towards apex (Fig. 2D). Collum blood-red, posterior margin pitch-black (Fig. 1A). Mesozona dorsolaterally with blood-red field not reaching down to 
ozopore. Metazona pitch-black (Fig. 1B). Species distributed around Ranomafana National Park (Fig. 6) ............................................................. A. cowani

4b Posterior gonopod, mesal membranous fringe developed into erect process, but also extending into more apically oriented area (Fig. 14C). Telopodite becoming wider towards apex (Fig. 14B). Body rings 1-3 and telson completely blood-red, remaining body rings pitch-black. Distributed in the Ambohijanahary mountains, Western Madagascar (Fig. 6). A. sanguineus $\mathbf{n}$. sp.

5a Anterior gonopod retrorse process located apically on swollen appendage (Fig. $8 \mathrm{~A})$. Posterior gonopod, basal branch only slightly shorter but wider than telopodite (Fig. 8B). Telopodite main branch laterally with characteristic large, triangular membranous lobe (Fig. 8B). Apex of telopodite appears swollen because of membranous fringes. Species distributed in rainforests in Northern Madagascar (Fig. 6) A. erythrocephalus

5b Anterior gonopod retrorse process located mesally on swollen appendage (Fig. 11D). Posterior gonopod, basal branch slimmer and much shorter than telopodite (Fig. 11B). Telopodite main branch laterally with numerous membranous fringes (Fig. 11C) A. hova

6a Posterior gonopod basal branch width strongly increasing mesally or before apex (Figs 12A, 15B). Tips of telopodite and basal branch touching (Figs 12B, 15C) ...7

6b Posterior gonopod main branch width not strongly increasing (Figs 16D, 19C). Tips of telopodite and basal branch close, but never touching (Figs 17C, 20)... 8

7a Posterior gonopod, main branch without membranous folds (Fig. 12B). Basal branch with some membranous fringes at apex. All body rings with a pale red, brown color pattern (Fig. 7B). Blood-red color only on head, antenna and legs (Fig. 1C). Species distributed in rainforests around Fort Dauphin (Fig. 6) ... A. corallipes

$7 \mathbf{b}$ Posterior gonopod shape unique; membranous fringes present on main branch, but absent on basal branch (Fig. 15C). Telopodite basal branch medially strongly swollen, apex slim and curved (Fig. 15B). Body rings dorsolaterally with blood-red pattern. Species known from Isaka-Ivondro and Sainte Luce (Fig. 6)

A. infernalis n. sp.

8a Membranous folds absent mesally on posterior gonopod main branch (Fig. 16C). Anterior gonopod retrorse process located apically on swollen appendage (Fig. 16B). Collected in PN Midousy (Fig. 6). A. diabolicus n. sp.

8b Membranous folds present mesally on posterior gonopod main branch (Figs 17C, 20)

9a Antenna extending back to body ring 4 (Fig. 1G). Male prefemur 3-5 medially with shallow invagination (Fig. 17A). Anterior gonopod coxite process longer than telopodite (Fig. 17B). Head completely red (Fig. 1G). Distributed in the Southern spiny forest ecosystem (Fig. 6) A. aridus n. sp.

9b Antenna extending back to body ring 6 (Fig. 1H). Anterior gonopod coxite process as long as telopodite (Fig. 19B). Head only at anterior margin red (Fig. 1H). Distributed in the Andohahela mountain chain, North of Isaka-Ivondro (Fig. 6). 


\section{Aphistogoniulus cowani (Butler, 1882)}

Spirostreptus cowani Butler, 1882: 328. Type data: male holotype, female paratype (BM82-26), examined.

Spirobolus cowani - Pocock 1893: 249.

Trigoniulus sanguinemaculatus Silvestri, 1897a: 18, pl. 3, figs. 18-20, new synonym Aphistogoniulus sanguinemaculatus - Silvestri 1897b: 651; Jeekel 1971: 36; Enghoff 2003: 623 (lists species name).

Aphistogoniulus cowani-Jeekel 1971: 35; Enghoff 2003: 623 (lists species name). Aphistogoniulus aff. corallipes - Enghoff 1996: 91.

\section{Material examined: $15 \mathrm{M}, 16 \mathrm{~F}$}

Holotype: 1 M, BM 82-26 (Natural History Museum, London), Madagascar, Province Fianarantsoa, "Betsileo Country, Ankafana", probably South Betsileo, forest of Ankafina, $21^{\circ} 12^{\prime} \mathrm{S}, 47^{\circ} 12^{\prime} \mathrm{E}$, montane rainforest, $1300 \mathrm{~m}$.

Paratype: $1 \mathrm{~F}$, same data as holotype.

Other material examined: 1 F, 1 imm., CAS BLF 8403, Province Fianarantsoa, Parc National de Ranomafana, Vatoharanana River, $4.1 \mathrm{~km} 231^{\circ} \mathrm{SW}$ Ranomafana, montane rainforest, 1100 m, 21 17'24”S, 047²6’00”E, coll. Fisher, Griswold et al., 27-31.iii.2003; 1 M, 3 F, CAS no number, Province Fianarantsoa, Ranomafana National Park, Talatakely, $900 \mathrm{~m}$, mixed tropical forest, $21^{\circ} 15^{\prime} 1.48^{\prime} \mathrm{S}, 47^{\circ} 25^{\prime} 10.02^{\prime} \mathrm{E}$, coll. D. H. \& K. M. Kavanaugh, R. L. Brett, E. Elsom, F. Vargas, 2-22.i.2001; 1 M, 1 F, CAS no number, Province Fianarantsoa, PN Ranomafana, Talatakely, 21 ${ }^{\circ} 15^{\prime}$ S, 47²6'E, 915-1000m, coll. Lee \& Ribardo, 30.x.-20.xi.1998; 1 imm., CAS no number, same data as previous; $1 \mathrm{M}, 1 \mathrm{~mm}$., CAS no number, same data as previous, but 940 m; 1 M, FMMC 7791, Province Fianarantsoa, extreme Northern limit of RS Ivohibe, mid-elevation forest, $1200 \mathrm{~m}, 22^{\circ} 28.2^{\prime} \mathrm{S}, 46^{\circ} 57.6^{\prime} \mathrm{E}$, coll. S. Goodman, 3-9.ix.1997, pitfall trap; 1 F, FMMC 7792, same data as previous; $1 \mathrm{~F}$, FMMC 7795, same data as previous; 1 imm., FMMC 7866, same data as previous; 1 M, FMMC 7867, same data as previous; 1 F, FMMC 7868, same data as previous; 2 M, FMMC 7877, same data as previous; 3 M, 1 F, 1 imm. ZMUC 100943, Province Fianarantsoa, Andringitra Reserve, ca. $40 \mathrm{~km} \mathrm{~S} \mathrm{Ambalavao,} \mathrm{along}$ Volotsangana River, 1210 m, 22¹3'22”S, 4658'18”E, coll. 5-6.xii.1993, S. Goodman; 4 M, 3 F, ZMUC 100944, Andringitra Reserve, on ridge east of Volotsangana River, $1625 \mathrm{~m}, 22^{\circ} 11^{\prime} 39^{\prime}$ 'S, 4658'16”E, coll. S. Goodman, 12-13.xii.1993; 2 F 2 imm., ZMUC 100945, Province Fianarantsoa, PN Ranomafana, Talatakely, 900 m, 21 ${ }^{\circ} 15^{\prime}$ S, 47²5’E, coll. N. Scharff, S. Larcher, C. Griswold, R. Andriamasimanana, 5-7.xii.1993; 1 F, ZMUC 100946, PN Ranomafana, Vohipara, 900 m, $21^{\circ} 14$ 'S, $47^{\circ} 24^{\prime} E$, coll. N. Scharff, S. Larcher, C. Griswold, R. Andriamasimanana, 5-7.xii. 1993 .

Diagnosis: males up to $120 \mathrm{~mm}$ long, $8.6 \mathrm{~mm}$ wide with $48-53$ body rings. Head and anterior $2 / 3$ of collum red, posterior $1 / 3$ of collum pitch-black. Mesozona dorsolaterally with blood-red field not reaching down to ozopore. Metazo- 
na pitch-black (Fig. 1B). Posterior gonopod telopodite main branch with lateral membranous fringe strongly developed into erect process (Fig. 2B). Main branch becoming only slightly thicker from beginning of fringe towards apex (Fig. 2D). A lateral membranous fringe is also present in $A$. sanguineus $\mathbf{n}$. sp., but here the main branch is of a slightly different shape. The fringe in A. sanguineus $\mathbf{n}$. sp. is closer to the apex (Fig. 14C) than in $A$. cowani (Fig. 2C). The anterior gonopod appendage is wide and swollen in A. cowani (Fig. 2A) while it is more slender in A. sanguineus n. sp. (Fig. 14A).

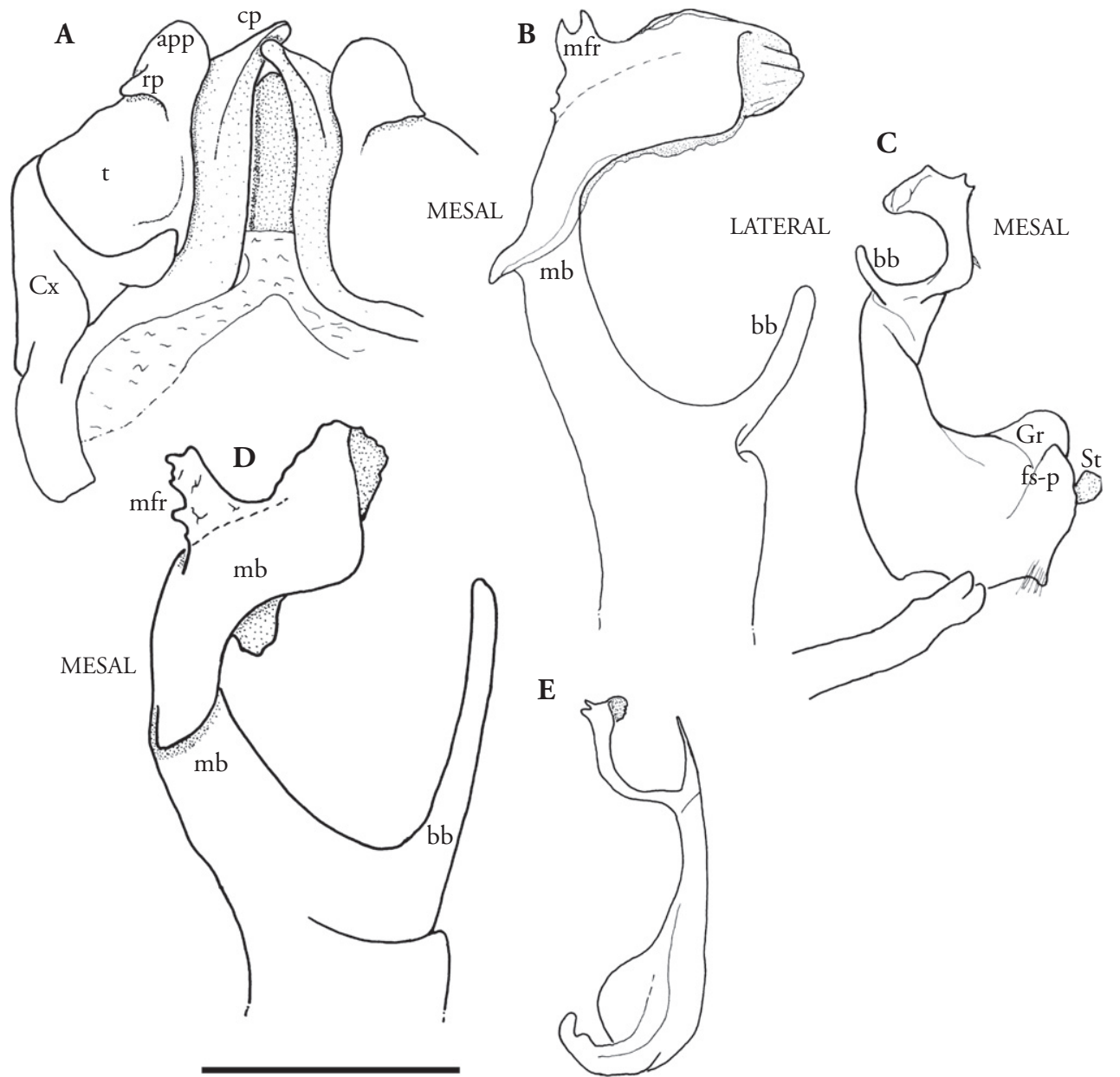

Figure 2. A. cowani, A-C, male holotype (BM82-26), A: anterior gonopods, anal view; B: right posterior gonopod, oral view; C: right posterior gonopod, anal view; D: specimen from Ranomafana, right posterior gonopod, oral view (CAS no number); E: left posterior gonopod, anal view, redrawn from Silvestri's (1897) original description of $A$. sanguinemaculatus. Abbreviations: app = appendage; bb = basal branch; $\mathrm{Cx}=$ coxite $\mathrm{cp}=$ coxite process; $\mathrm{fs}-\mathrm{p}=$ finger-shaped process; $\mathrm{Gr}=$ coxite groove; $\mathrm{mb}=$ main branch; $\mathrm{mfr}$ $=$ membranous fringe; $\mathrm{rp}=$ retrorse process; $\mathrm{St}=$ sternite; $\mathrm{t}=$ telopodite. Drawings not to scale. 
Description: Measurements: 90-120 mm long, 8.6-10.5 mm wide, with 48-53 body rings.

Color head, antenna, legs and telson blood-red in freshly preserved specimens (Fig. 1B). Collum red except for thin black stripe at posterior margin (Fig. 1A). Metazonites dorsolaterally with a red field, remaining parts of body rings black. Rings dorsally with a thick black line.

Antenna short, extending back to third body ring. Fifth antennomere latero-apically with five rows (Fig. 3B), sixth antennomere with four rows of sensilla basiconica in both sexes (Fig. 3D). Gnathochilarium median palps each with 11-13 sensory cones (Fig. 4E)

Anterior gonopod sternite triangular and well-rounded (Fig. 2A). Coxite process extending as long as telopodite tip (Fig. 2A, $c p$ ). Telopodite appendage (app) strongly swollen. More or less well-rounded retrorse process located on higher level than appendage.

Posterior gonopod telopodite branches forming a 'C' (Fig. 2C). Basal branch short, slim and inconspicuous, without membranous folds (Fig. 2B). Tip of main branch apically and laterally with membranous fringe of species-specific shape (Figs 2B, D). Width of branch increasing towards tip.

Intraspecific variation: two females from Ranomafana (CAS no number) are significantly smaller than the others, with a body length of $89 \mathrm{~mm}, 91 \mathrm{~mm}$ and a width of $8.6 \mathrm{~mm}, 8.9 \mathrm{~mm}$ respectively. There is a slight difference in the ring number and shape of posterior gonopods between the holotype from the Ankafina forest (Fig. 2B) and the specimens from Ranomafana (Fig. 2D). The holotype has 53 body rings, while all specimens from Ranomafana have 48 rings. The specimens from Ivohibe have 48-49
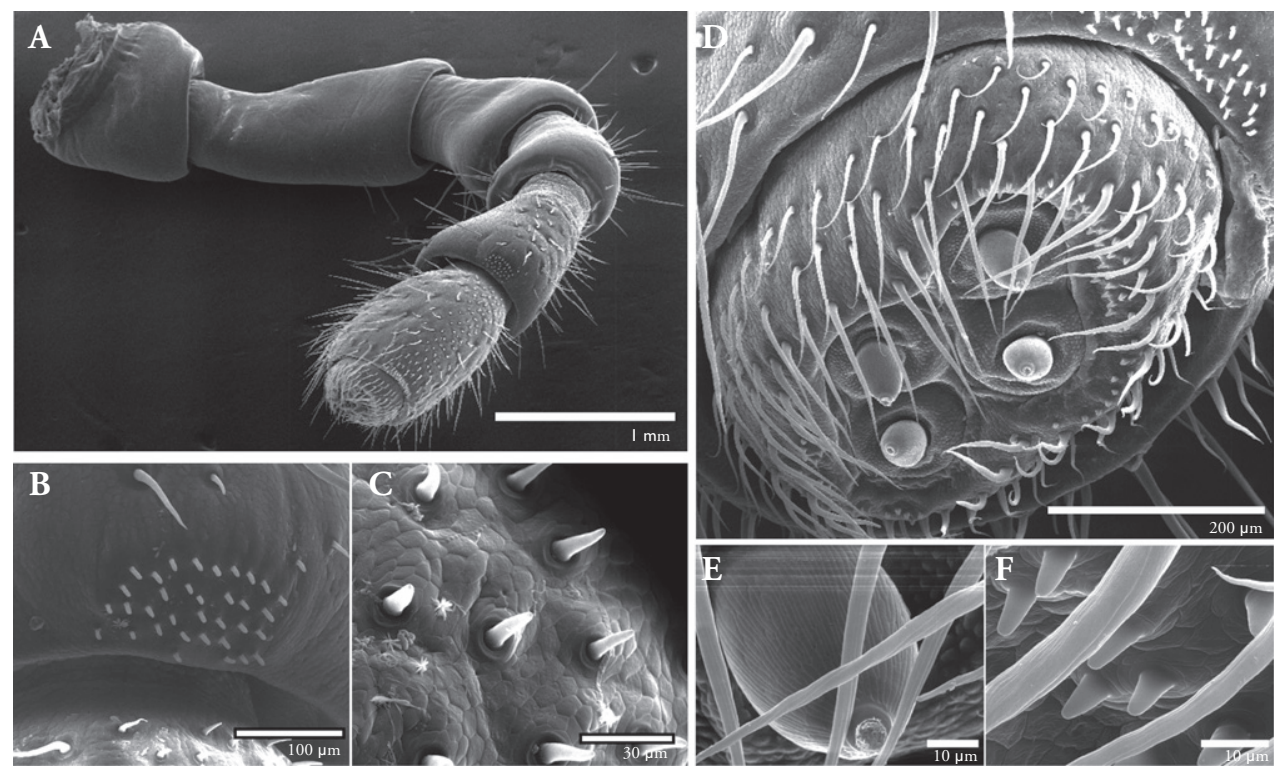

Figure 3. SEM, A. cowani, male (CAS no number), antenna, A: overview; B: sensory cones (sensilla basiconica) latero-apically on 5th antennomere; $\mathbf{C}$ : sensory hairs basally on 6th antennomere; $\mathbf{D}$ : apical view on 7th antennomere; E: detail of sensory cone; F: sensory cones on disc, detail. 
body rings. These specimens display a slightly different color pattern: while in specimens from Ranomafana only the posterior third of the collum is black, in specimens from Ivohibe almost the whole posterior half is black. There are also slight differences in the posterior gonopods between specimens from Ivohibe and Ranomafana.

Remarks: the type specimen of $A$. sanguinemaculatus was not studied, but the posterior telopod illustrated by Silvestri (redrawn in Fig. 2E) is identical in all details to those of. A. cowani (Fig. 2B). Synonymy of $A$. cowani and A. sanguinemaculatus was already suggested by Jeekel (1971) and is herewith formalized.

Conservation and distribution: satellite images show that the type locality, the forest of Ankafina (Fig. 6), no longer has a closed canopy. The forest of Ankafina is separated from the other known localities 25 kilometers to the east inside the PN Ranomafana by an area of pseudosteppe (Fig. 6).
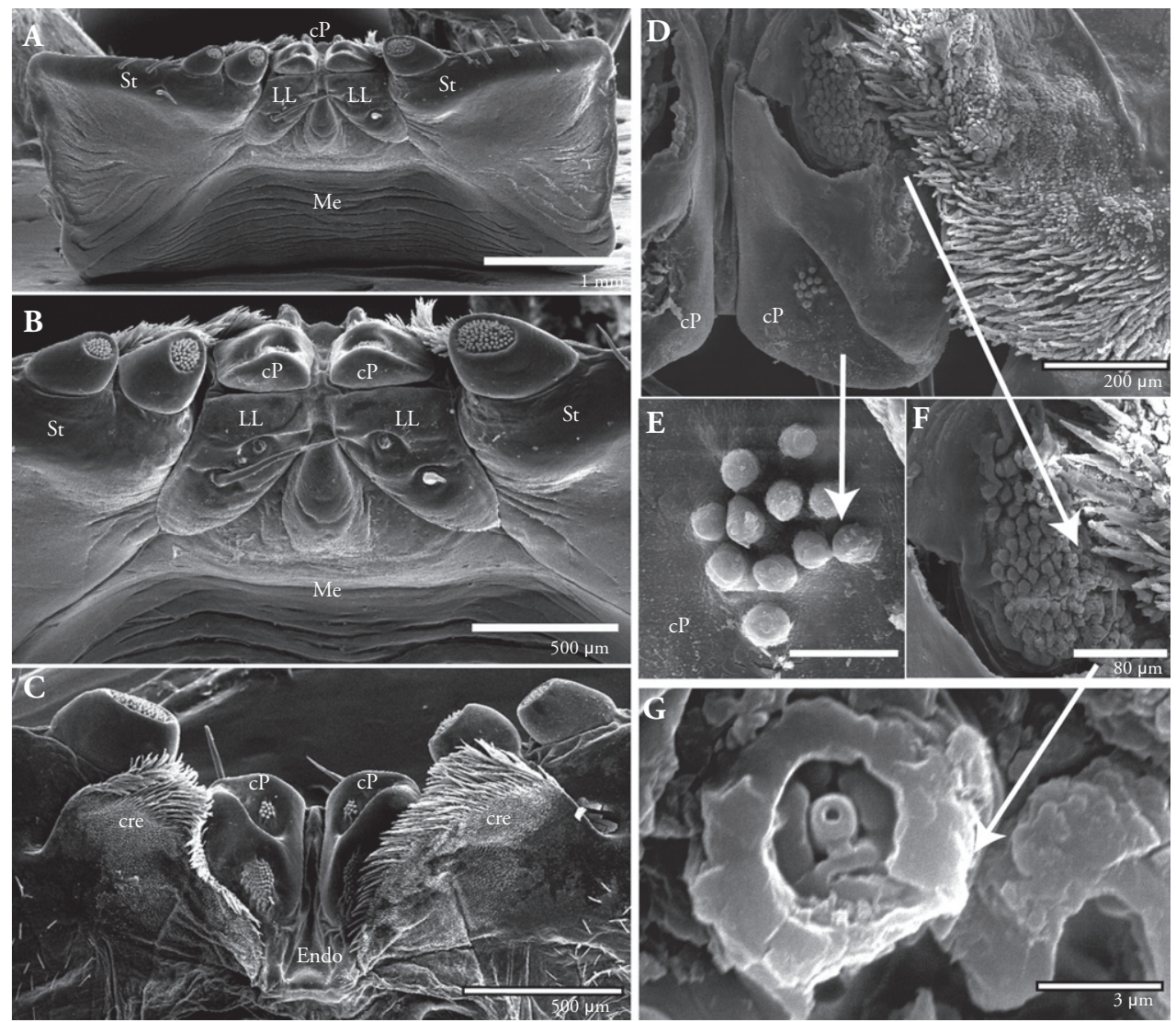

Figure 4. SEM, A. cowani, A-C male, D-G female (CAS no number), gnathochilarium, A: ventral side, apical view; B: detail of median part, apical view; $\mathbf{C}$ : dorsal view, central located pads and endochilarium; D: detail of endochilarium; E: sensory cones on central pads, median; F: sensory cones on endochilarium, overview; G: detail of single sensory cone on endochilarium. Abbreviations: $\mathrm{cP}=$ central located pad, median palp; cre = hypopharyngeal crest Endo = endochilarium; LL = lamella lingualis; $\mathrm{Me}=$ mentum; $\mathrm{St}=$ stipes. 

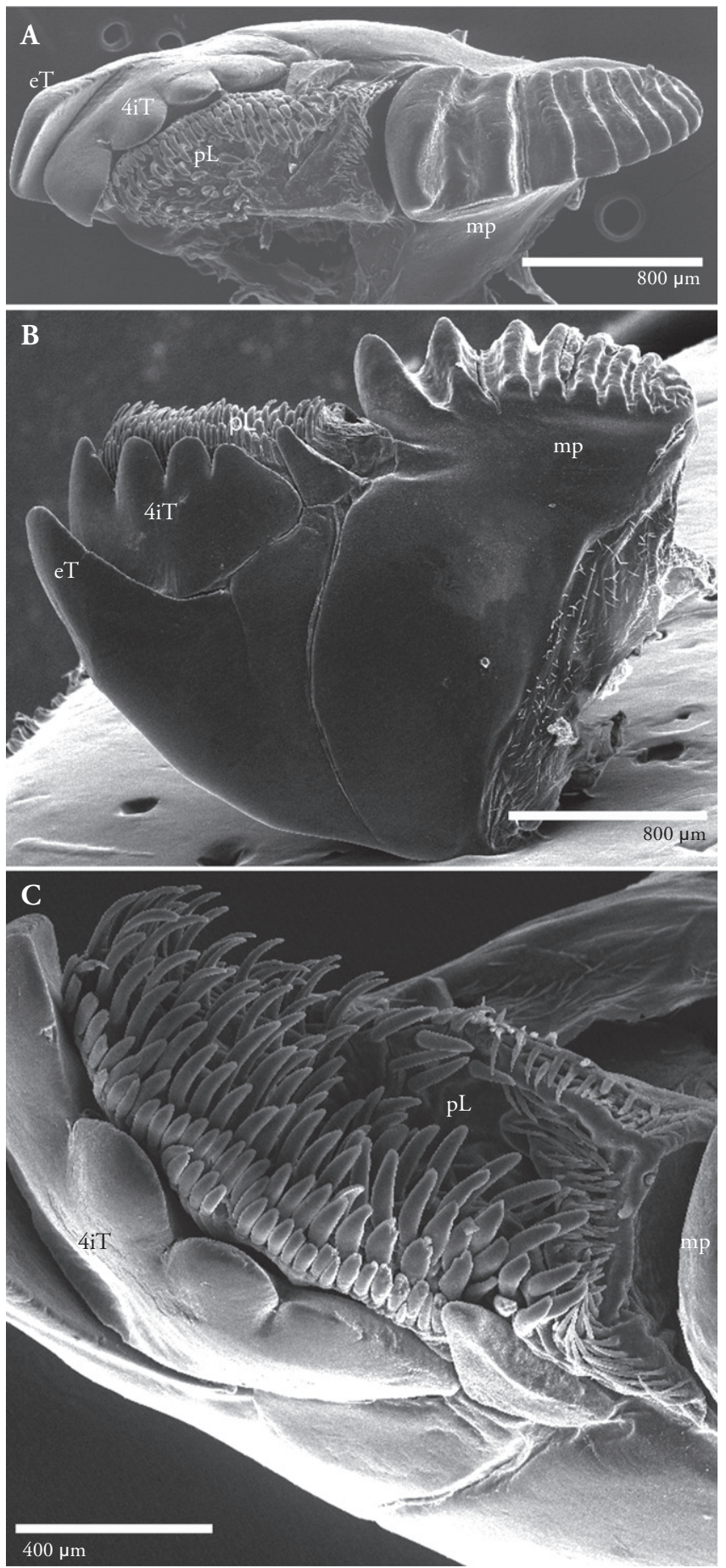

Figure 5. SEM, A. cowani (CAS no number), mandible, A: female, mesal view; B: male, ventral view; C: male, detail of pectinate lamella. Abbreviations: 4iT = 4-combed inner tooth; eT = external tooth; $\mathrm{mp}=$ molar plate; $\mathrm{pL}=$ pectinate lamella. 


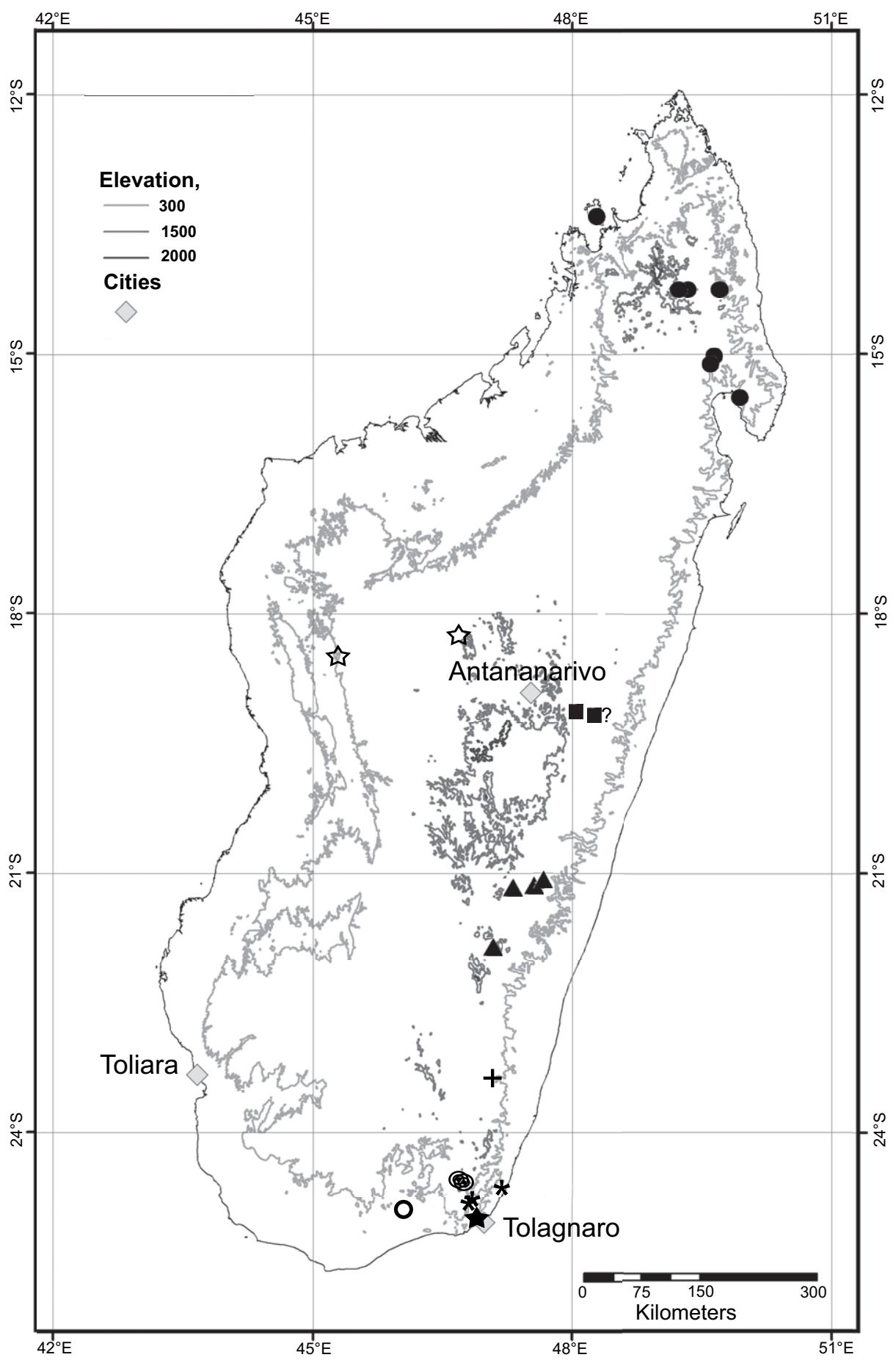

Figure 6. Distribution map of the Aphistogoniulus species on Madagascar: $(\mathbf{\Delta})-A$. cowani; $(\mathbf{O})-A$.

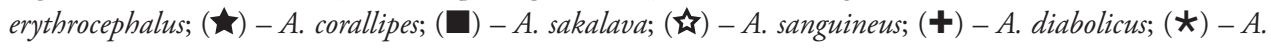
infernalis; (О) - A. aridus; (()) - A. vampyrus. 


\section{Aphistogoniulus erythrocephalus (Pocock, 1893)}

Spirobolus erythrocephalus Pocock, 1893: 250, pl. 16, fig. 2, Type data: male holotype, (BM1891.11.21.5), examined.

Mystalides quadridentatus Attems, 1910: 95, figs 11-12, pl. 12, figs 42-43, new synonym, type Natural History Museum, Vienna, not examined.

Aphistogoniulus erythrocephalus - Jeekel 1971:35; Enghoff 2003: 623 (lists species name). Aphistogoniulus quadridentatus - Jeekel 1971: 36, figs 1-2; Enghoff 2003: 623 (lists species name).

Material examined: $24 \mathrm{M}, 7 \mathrm{~F}$

Holotype: M, BM 1891.11.21.5 (Natural History Museum, London), NorthMadagascar.

Other material examined: $2 \mathrm{M}$, CAS BLF 8007, Province Toamasina, Montagne

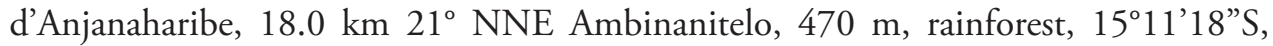
049³6 54”E, coll. Fisher, Griswold et al., 8-12.iii.2003; 1 M, CAS BLF 8152, Province Toamasina, Montagne d'Anjanaharibe, $19.5 \mathrm{~km} 27^{\circ}$ NNE Ambinanitelo, 1100 $\mathrm{m}$, montane rainforest, $15^{\circ} 10^{\prime} 42^{\prime \prime} \mathrm{S}, 049^{\circ} 38^{\prime} 06^{\prime \prime} \mathrm{E}$, coll. Fisher, Griswold et al., 12-16. iii.2003; 1 M, 1 F, CAS BLF 8726, Province Antsiranana, PN de Marojejy, Manantenina River, $28.0 \mathrm{~km} 38^{\circ} \mathrm{NE}$ Andapa, $8.2 \mathrm{~km} 333^{\circ} \mathrm{NNW}$ Manantenina, $450 \mathrm{~m}$, rainforest, $14^{\circ} 26^{\prime} 12^{\prime \prime S}, 049^{\circ} 46^{\prime} 30^{\prime}$ E, coll. B. L. Fisher et al., 12-15.xi.2003; 2 M, 1 F, 1 imm., CAS BLF 8874, Province Antsiranana, PN de Marojejy, Manantenina River, $27.6 \mathrm{~km}, 35^{\circ} \mathrm{NE}$ Andapa, $9.6 \mathrm{~km} 327^{\circ} \mathrm{NNW}$ Manantenina, $775 \mathrm{~m}$, rainforest, 1426'06”'S, 04945'36"E, coll. B. L. Fisher et al., 15-18.xi.2003; 1 M, CAS DSD0006, Province Toamasina, PN Masoala, Ambohitsitondroina Mt., Ambanizana, $650 \mathrm{~m}$, rainforest, $15^{\circ} 34^{\prime} 10^{\prime \prime} \mathrm{S}, 050^{\circ} 00^{\prime} 12^{\prime \prime} \mathrm{E}$, coll. Andriamalala, Silva et al., 26.ii.06.iii.2003; 4 M, 4 F, 2 imm., FMMC 3925, Province Antsiranana, Nosy Be, RNI de Lokobe, $6.3 \mathrm{~km} 112^{\circ}$ ESE Hellville, $30 \mathrm{~m}$, rainforest, $13^{\circ} 25^{\prime} 10^{\prime \prime} \mathrm{S}$, 4819'52"E, coll. Fisher, Griswold et al., 19-24.iii.2001; 1 M, FMMC 5438, Province Antsiranana, Foret de Betaolana, along Ambolokopatrika River, $8.5 \mathrm{~km}$ NW Ambodiangezoka, 875 $\mathrm{m}$, rainforest, $14^{\circ} 32.3^{\prime} \mathrm{S}, 49^{\circ} 26.3^{\prime} \mathrm{E}$, coll. S. Goodman, 8-12.xi.1999, pitfall trap; $1 \mathrm{M}$, FMMC 5468, Province Antsiranana, near Analamozava River, $7.5 \mathrm{~km} \mathrm{SW}$ Daraina, undisturbed humid lowland forest, 325-600 m, 13⒖3'S, 49 37.0'E, coll. S. Goodman, 3-10.xi.2001, pitfall trap; 1 M, 2 F, FMMC 7846, Province Antsiranana, PN de Marojejy, 1625 m, montane rainforest, coll. S. Goodman; 1 M, FMMC 7877, Province Antsiranana, PN de Marojejy, $450 \mathrm{~m}$, rainforest, coll. S. Goodman; $1 \mathrm{M}$, FMMC 7896, Province Antsiranana, PN de Marojejy, $1225 \mathrm{~m}$, montane rainforest, coll. S. Goodman; 1 M, FMMC 7930, Province Toamasina, PN Anjanaharibe, 1200 m, montane rainforest, coll. S. Goodman; 1 M, FMMC 7934, Province Antsiranana, Forêt de Betaolana, $1200 \mathrm{~m}$, montane rainforest, coll. S. Goodman; $1 \mathrm{M}, 1 \mathrm{imm}$. F, ZMUC 100942, Province Antsiranana, Majoresy Res., 8.4 km NNW of Manantenina, 400-

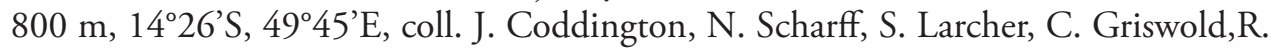
Andriamasimanana, 16.xi.1993; 1 M, ZMUC 100947, Majoresy Res., 8.4 km NNW 

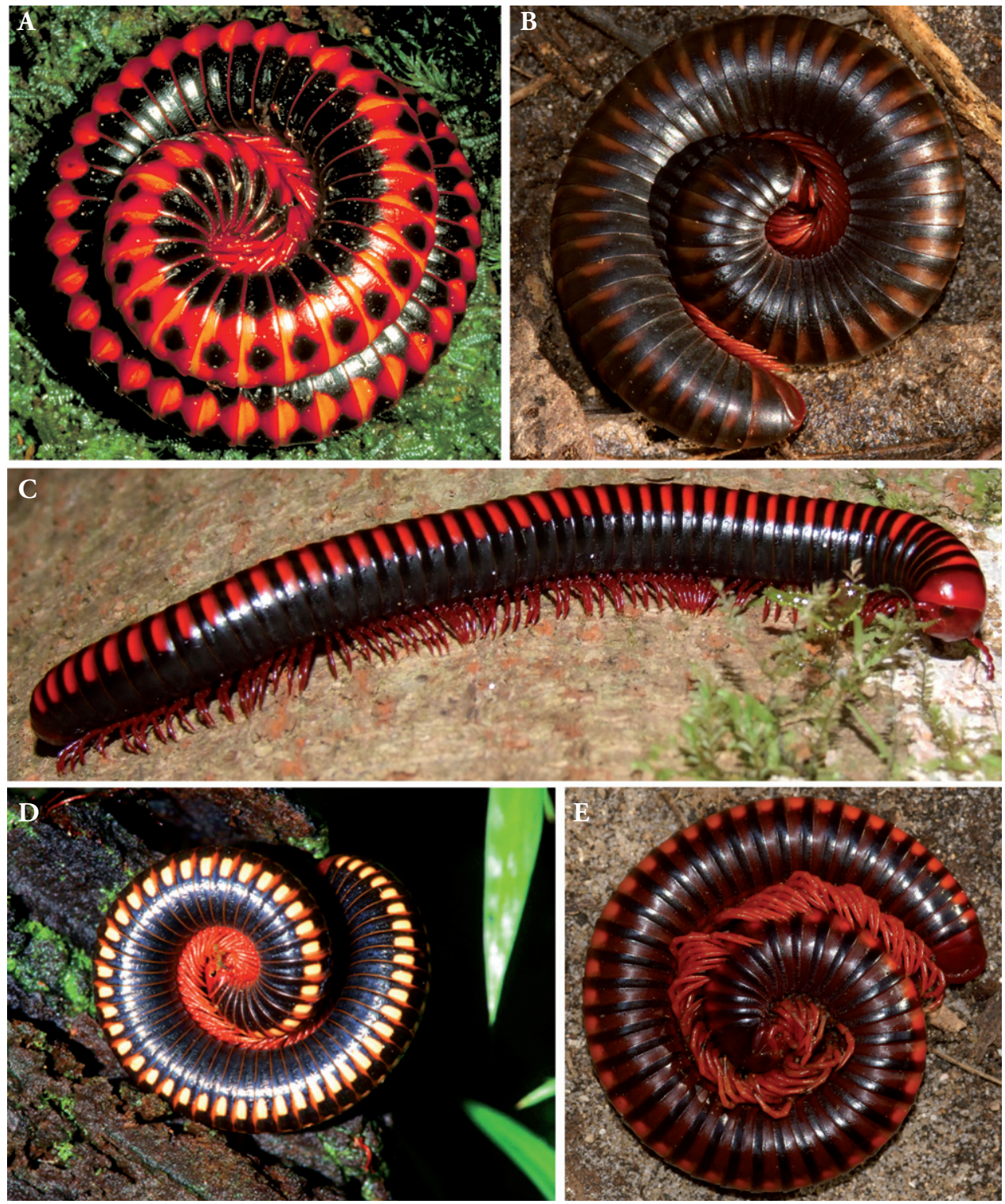

Figure 7. Photographs of living specimens, A: A. cf. erythrocephalus, male, photograph by D. R. Parks, all rights reserved; B: $A$. corallipes, male, from Manantantely, photograph by Kai Schütte; C: $A$. c $f$. sakalava, from Mantadia, Perinet, photograph by Arne Hartig, all rights reserved; D: A. cf. erythrocephalus, from Anjaharibe, photograph by Harald Schütz, all rights reserved; E: $A$. infernalis n. sp., male, from Sainte Luce, photograph by Thomas Wesener.

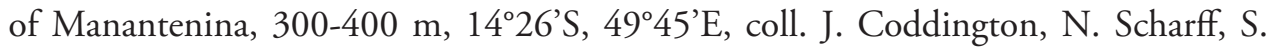
Larcher, C. Griswold, R. Andriamasimanana, 10-17.xi.1993.

Diagnosis: males circa $175 \mathrm{~mm}$ long, $13 \mathrm{~mm}$ wide with $52-62$ body rings. Anterior gonopod retrorse process located apically on swollen appendage (Fig. 8A). Posterior 
gonopod, basal branch as long as but wider than main branch (Fig. 8B). Main branch laterally with large, triangular membranous lobe (Fig. 8B). Apex of main branch appears swollen because of membranous fringes. The specific shape of the posterior gonopods, with membranous folds apically and laterally of the tip is similar to those of $A$. hova (Fig. 11B). A. erythrocephalus differs from $A$. hova in the shape and position of the anterior gonopod retrorse process. Furthermore, the posterior gonopod main branch tip is much wider in A. erythrocephalus (Fig. 8B) than in A. hova (Fig. 11C).

Description: Measurements: $125-175 \mathrm{~mm}$ long, $9.2-13 \mathrm{~mm}$ wide, with 52-62 body rings.

Color in living specimens red-black. Head, antenna, legs and telson red. Collum red except for thin black stripe at posterior margin (Fig. 7A). Metazonites dorsolaterally with red field, remaining parts of body rings black (Fig. 7D). Rings dorsally with thick black line, in some specimens disintegrated into row of spots (Figs 7A, D).

Antenna short, extending back to fourth body ring. Fifth antennomere latero-apically with five rows, sixth antennomere with four rows of sensilla basiconica in both sexes. Gnathochilarium median palps each with 10-11 sensory cones.

Anterior gonopod sternite in holotype not elongated, with two broadly rounded tips (Fig. 8A). Coxite process ( $c p$ ) shorter than telopodite (Figs 9A-C). Telopodite appendage $(a p p)$ strongly swollen, tip extending into strongly developed, well-rounded retrorse process (Fig. 8A, $r p$ ).

Posterior gonopod telopodite branches forming an 'O' (Fig. 8B). Basal branch long and wide, without membranous folds (Fig. 8B). Branch twice as wide and as long as main branch. Width of main branch increasing towards tip, apically and laterally with characteristic membranous fringe (Figs 9D-F).
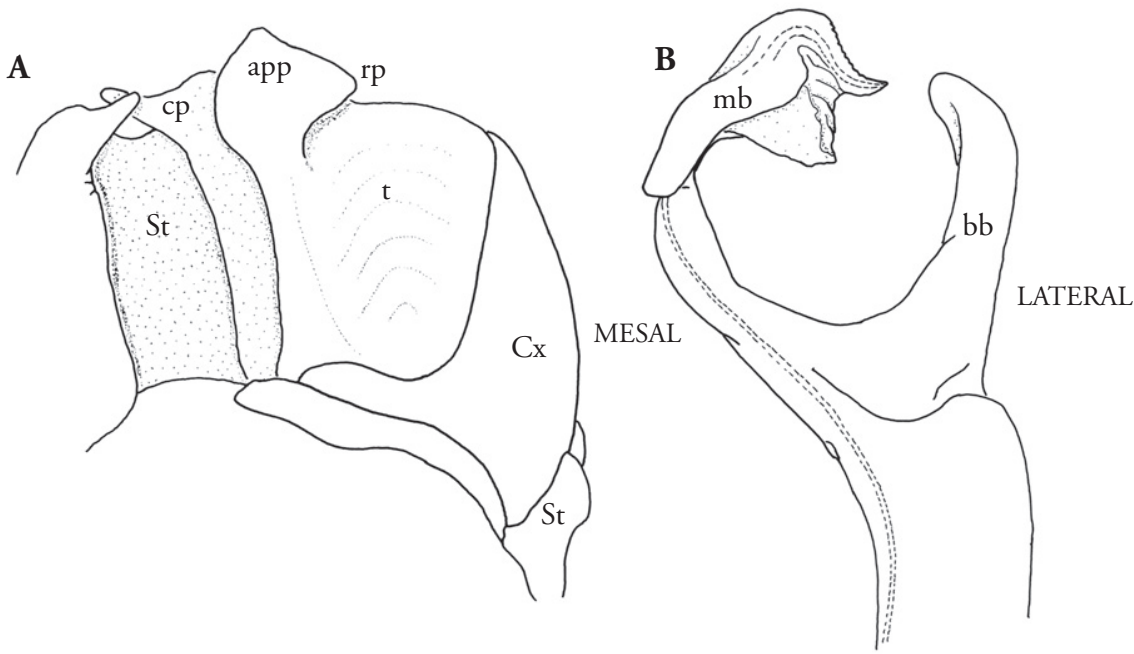

Figure 8. A. erythrocephalus, holotype (BM 1891.11.21.5), A: anterior gonopods, anal view; B: right posterior gonopod, oral view. Abbreviations: $\mathrm{app}=$ appendage; $\mathrm{bb}=$ basal branch; $\mathrm{Cx}=$ coxite; $\mathrm{cp}=$ coxite process; $\mathrm{mb}=$ main branch; $\mathrm{mfr}=$ membranous fringe; $\mathrm{rp}=$ retrorse process of appendage; $\mathrm{St}=$ sternite; $\mathrm{t}$ $=$ telopodite. Drawings not to scale. 

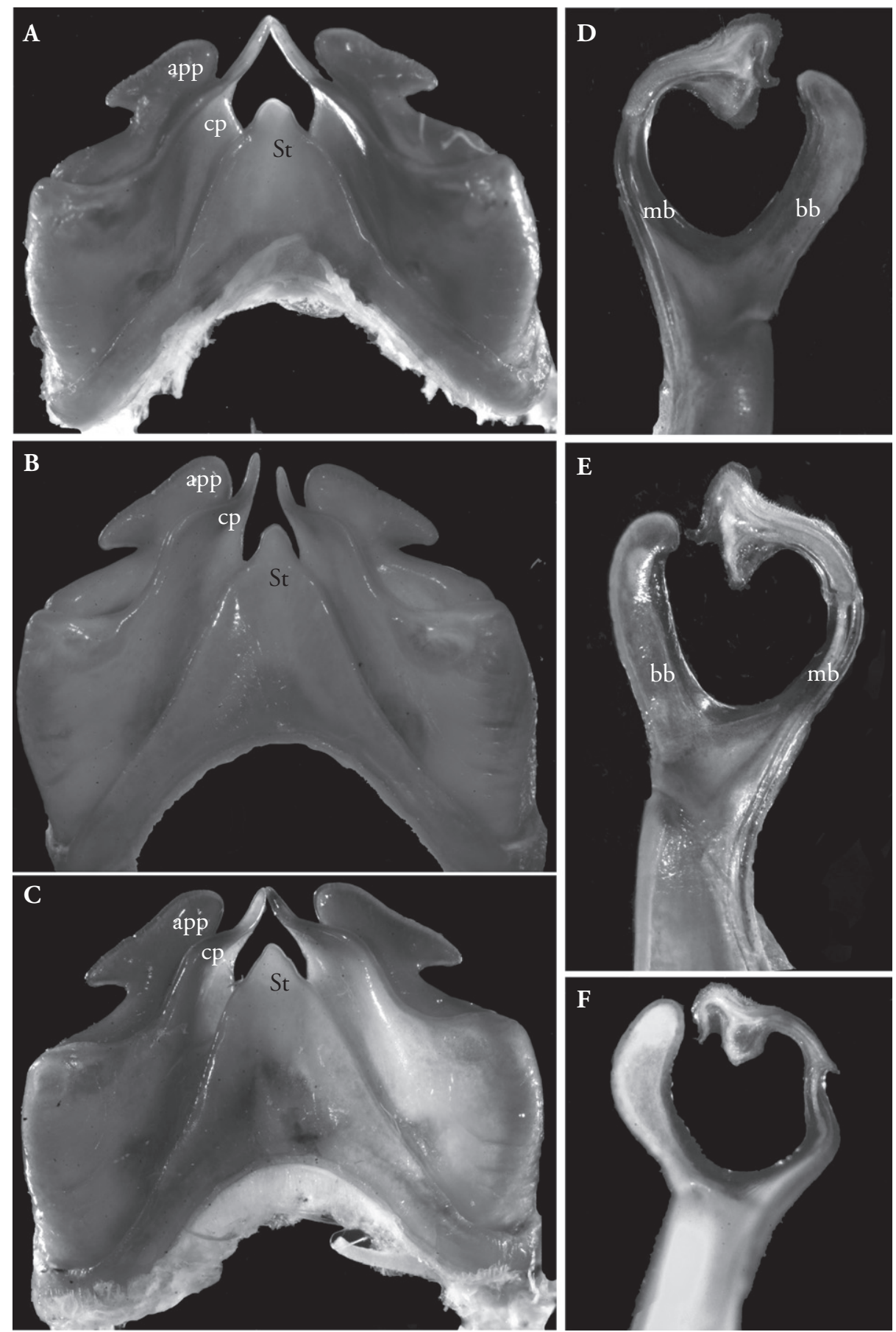

Figure 9. A. erythrocephalus, A-C anterior gonopods and D-F posterior gonopods, oral view, montage images, A: FMMC 7934; B: FMMC 7896; C: FMMC 7846; D: FMMC 3925; E: FMMC 7877; F: FMMC 7896. Abbreviations: $\mathrm{app}=$ appendage; $\mathrm{bb}=$ basal branch; $\mathrm{cp}=$ coxite process; $\mathrm{mb}=$ main branch; St = sternite. Figures not to scale. 

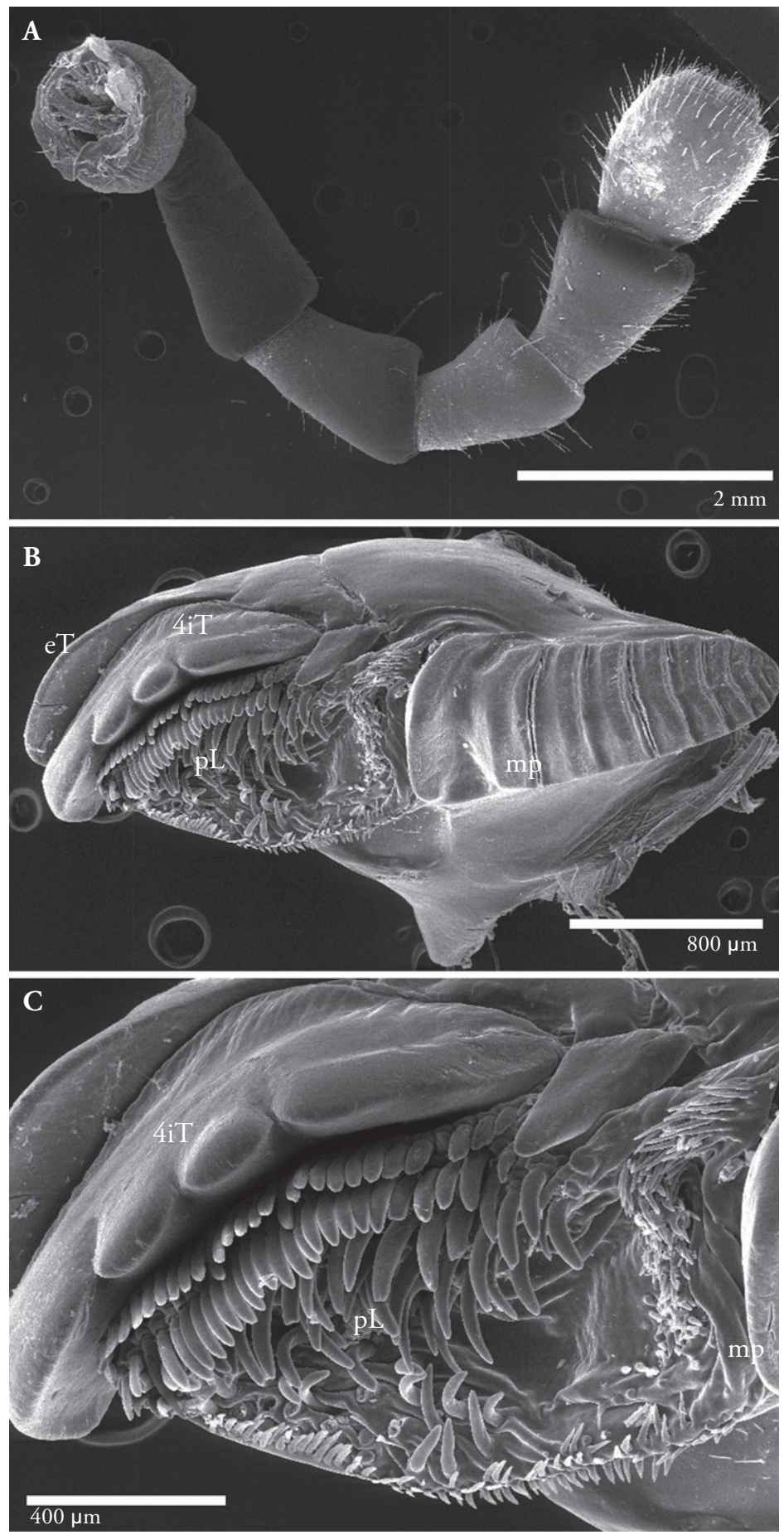

Figure 10. SEM, A. erythrocephalus, male (CAS DSD0006), A: antenna, overview; B: mandible, mesal view; C: mandible, pectinate lamella. Abbreviations: $4 \mathrm{iT}=4$-combed inner tooth; $\mathrm{eT}=$ external tooth; $\mathrm{mp}=$ molar plate $\mathrm{pL}=$ pectinate lamella . 
Intraspecific variation: the number of body rings differed by $1-3$ among specimens from the same locality. No direct correlation was found between the elevation of the locality and the number of body rings. The variation of the anterior gonopods could be studied in specimens from three localities (FMMC 7846, 7896, 7934) as well as in the holotype. No variation could be observed in the coxite and telopodite, but the sternite displays large differences in all observed individuals. The shape of the anterior gonopod sternite varies from consisting of two lobes (holotype, Fig. 8A), a single lobe with more (FMMC 7934, Fig. 9A) or less prominent shoulders (FMMC 7896, Fig. 9B), to a simple triangle (FMMC 7846, Fig. 9C). Posterior gonopods could be compared in specimens from seven localities (FMMC 3925, 5438, 7846, 7877, 7896, $7930,7934)$ as well as from the holotype. Not even the slightest variation was observed (Figs 8B, 9D-F).

Remarks: the type specimen of $A$. quadridentatus was not studied, but it was well illustrated by Jeekel (1971). A synonymy of $A$. erythrocephalus and A. quadridentatus was already suggested by Jeekel (1971) and is formalized here.

Conservation and distribution: $A$. erythrocephalus belongs to a handful of Malagasy millipede species with a wide area of distribution (Fig. 6). Specimens could be collected in numerous rainforest and montane rainforest areas in Northern Madagascar, including the island of Nosy Be. A. erythrocephalus was found in forests almost on sea level (Nosy Be: Lokobe) as well as very high up in mountains (Marojejy: $1625 \mathrm{~m}$ ).

Aphistogoniulus hova (de Saussure \& Zehntner, 1897)

Spirobolus hova de Saussure \& Zehntner, 1897: pl. 11, fig. 44. Type data: male lectotype (designated herewith), MNHN HB029, examined. Type locality: Madagascar. Spirobolus (Trigoniulus) hova - de Saussure \& Zehntner 1902: 146.

Mystalides hova - Brolemann 1922: 241, figs 18-25.

Aphistogoniulus hova-Jeekel 1971: 35, figs 5-6; Enghoff 2003: 623 (lists species name). Aphistogoniulus polleni Jeekel, 1971: 38, figs 3-4, new synonym, type Zoologisk Museum Amsterdam, not examined.

Aphistogoniulus brolemanni Jeekel, 1971: 39. new synonym, type specimen lost.

\section{Material examined: $3 \mathrm{M}$}

Lectotype (designated herewith): M, MNHN HB029, Madagascar, coll. Lantz 1871, det. H. de Saussure.

Other material examined: 1 M, MNHN HB029, Madagascar, Catat 938-90, det. H. de Saussure; 1 M, MNHN HB029, North Madagascar, coll. M. Lecovre, 03.ii.1989.

Diagnosis: males up to $120 \mathrm{~mm}$ long, $11.4 \mathrm{~mm}$ wide with 54-57 body rings. Anterior gonopod retrorse process located medially on swollen appendage (Fig. 11D). Posterior gonopod basal branch slimmer and much shorter than main branch (Fig. 11B). Telopodite main branch apically with numerous membranous fringes (Fig. 11C). See A. erythrocephalus for a list of the differences between both species. 


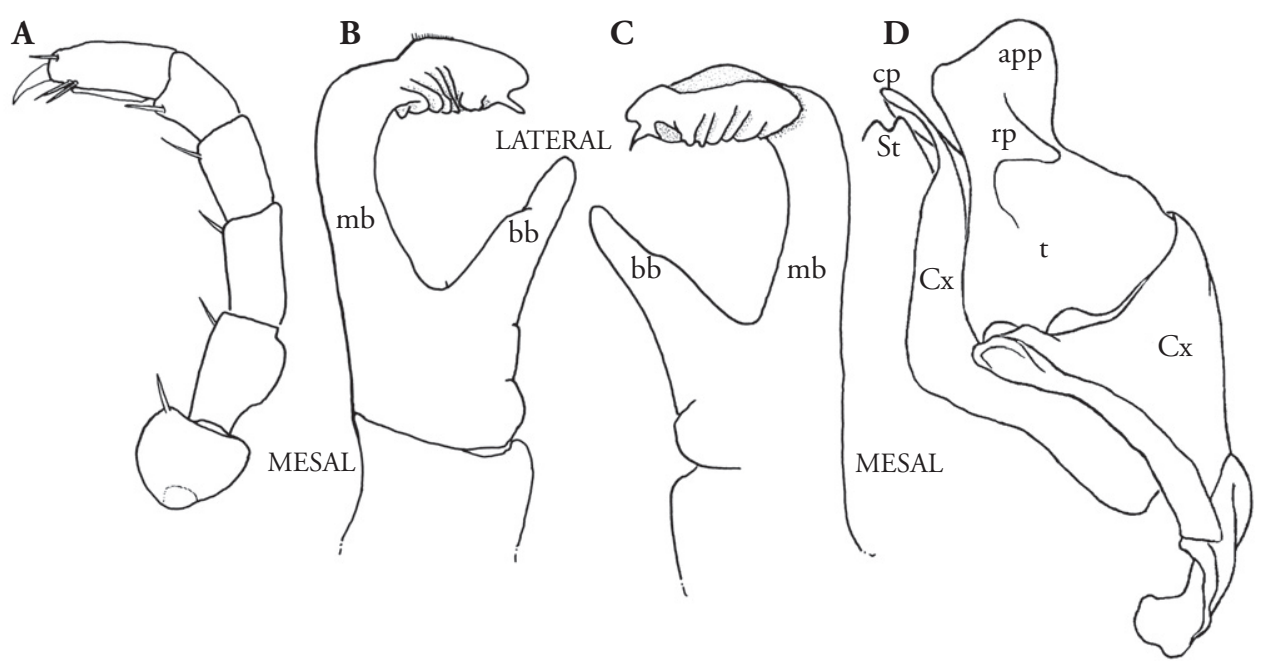

Figure 11. A. hova, A-C lectotype (MNHN HB029), D type specimen from MNHG, A: midbody left leg, anal view; B: right posterior gonopod, oral view; C: right posterior gonopod, anal view; D: left half of anterior gonopod, anal view (after original drawing by Hoffman published in Jeekel 1971). Abbreviations: $\mathrm{app}=$ appendage; $\mathrm{bb}=$ basal branch; $\mathrm{Cx}=$ coxite; $\mathrm{cp}=$ coxite process; $\mathrm{mb}=$ main branch; $\mathrm{rp}=$ retrorse process of appendage; $\mathrm{St}=$ sternite; $\mathrm{t}=$ telopodite. Drawings not to scale.

Description: Measurements: lectotype: 57 body rings, circa $120 \mathrm{~mm}$ long, at midbody rings $11.4 \mathrm{~mm}$ wide.

Color in preserved specimens similar to A. erythrocephalus. Body rings dorsally with row of large black dots, one dot on each body ring. Antenna short, extending to fourth body ring.

Anterior gonopod sternite in lectotype apically with two rounded tips. Coxite process as long as telopodite tip. Telopodite appendage extraordinarily strongly swollen. Retrorse process strongly developed, well-rounded. Retrorse process projecting medially, not apically as in other Aphistogoniulus species.

Posterior gonopod telopodite branches forming a ' $\mathrm{C}$ '. Basal branch slim and relatively short, with prominent notch at its inner margin (Fig. 11B). Basal branch as wide as and half as long as main branch. Width of main branch apically increasing: at tip with membranous fringe extending along lateral edge of curved branch (Figs 11B, C).

Intraspecific variation: the specimens collected by Catat and Lecovre (both MNHN HB029) have 55 body rings and are 12.2-12.5 mm wide. The holotype of A. polleni has, according to the literature (Jeekel 1971), 54 body rings and is $11.8 \mathrm{~mm}$ wide, while the types of $A$. brolemanni have 55-56 body rings (Brolemann 1922). According to Brolemann, the male of $A$. brolemanni is $8.5 \mathrm{~mm}$ wide, but it is unclear if the measurement is from the adult male or the juvenile male also present in the original type series of $A$. brolemanni (which is now lost).

Remarks: only part of the type series located at the MNHN was studied. The series included, in addition to the lectotype, numerous specimens of $A$. erythrocephalus 
collected from localities all over Madagascar, as well as a sample of $A$. cf. aridus $\mathbf{n}$. sp. We selected a male whose gonopods mirror those illustrated by de Saussure \& Zehntner (1897, pl. 11, fig. 44) as the lectotype for $A$. hova. The specimen was already dissected, presumably by Henri de Saussure himself. Unfortunately, no type locality is given except for 'Madagascar'. The posterior gonopods of $A$. hova mirror perfectly those illustrated of $A$. polleni and A. brolemanni (Jeekel 1971: fig. 4, Brolemann 1922: figs 18-25). The main arguments by Jeekel (1971) for separating $A$. polleni and $A$. brolemanni from $A$. hova and describing those as new species was the difference in ring number and width as well as slight differences in the shape of the anterior gonopods. The width and number of rings stated for $A$. hova by Jeekel (1971) were probably extracted from the original description. However, the real measurements of the lectotype of $A$. hova agree with those of $A$. polleni and A. brolemanni. The slight differences observed in the anterior gonopods can be explained by a perspective error. Specimens described as Mystalides hova by Brolemann (1922) were selected as types of A. brolemanni by Jeekel, 1971. The specimens were stored at the Academy Malgache in Antananarivo, Madagascar, an institution which no longer exists. The collections at Tsimbazaza, Antananarivo, which holds some of the insect specimens formerly stored at the Academy Malgache, did not include any millipede material. The type specimens of $A$. brolemanni are therefore considered lost.

Conservation and distribution: although specimens of $A$. hova were obviously collected at least five times in the past, no precise locality is known. Even the specimen collected 1989 by Lecovre just has 'North Madagascar' as locality information. The specimens described by Brolemann (1922), which we have not seen, were labelled Tanarive, which is now the capital Antananarivo. This locality information is dubious at best since numerous samples collected in the central highlands were all labelled 'Tanarive'. A. hova is the only known Aphistogoniulus species with an unknown area of occurrence. No specimens of $A$. hova could be found in recently collected material in the CAS or FMNH collections.

Aphistogoniulus corallipes (de Saussure \& Zehntner, 1902)

Spirobolus (Trigoniulus) corallipes de Saussure \& Zehntner, 1902: 143, pl. xv, fig. 13. Type data: male lectotype designated herewith (MNHN HB020), examined. Aphistogoniulus corallipes - Jeekel 1971: 36; Enghoff 2003: 623 (lists species name).

Material examined: $31 \mathrm{M}, 20 \mathrm{~F}$

Lectotype (designated herewith): M, MNHN HB020, Madagascar, Province Toliara, Fort Dauphin (Tolagnaro), coll. Ch. Alluaud, 1901, det. H. de Saussure.

Paralectotypes: 1 F, 1 imm., same data as lectotype.

Other material examined: 30 M, 19 F, Madagascar, Province Toliara, Private Reserve Manantantely, rainforest, $24^{\circ} 59^{\prime} 17.14^{\prime \prime S}, 046^{\circ} 55^{\prime} 27.95^{\prime \prime}$ E, coll. T. Wesener et al., 06.vi.2007. 
12 M, 7 F. were sent to the FMNH; 1 M, 1 F, CAS; 1 M, 1 F, ZMUC; 1 M, 1 F, ZMH; 1 M, 1 F, ZSM; 15 M, 9 F, sent as vouchers to the University Antananarivo.

Diagnosis: males up to $98 \mathrm{~mm}$ long, $8.1 \mathrm{~mm}$ wide with $48-50$ body rings. Body rings with orange, brownish black color pattern (Fig. 7B). Color dark brown instead of pitch-black; blood-red color only on head, antenna and legs (Fig. 1C). Anterior gonopod retrorse process located apically on swollen appendage (Fig. 13B). Posterior gonopod main branch lacking membranous folds (Fig. 12B). Basal branch with some membranous fringes at apex.

The specific shape of the posterior gonopods, with membranous folds apically and mesally on the basal branch tip, is similar to those in $A$. aridus $\mathbf{n}$. sp. and $A$. vampyrus n. sp. A. corallipes differs from these in coloration (Fig. $7 \mathrm{~B}$ ), the presence of a slender, finger-shaped process apically on the posterior gonopod main branch (Fig. 12B), and in the presence of a wide, circular extension latero-apically on the posterior gonopod basal branch (Fig. 12A).

Description: Measurements: males: 49 or 50 body rings, circa $90 \mathrm{~mm}$ long, 7.5$8.1 \mathrm{~mm}$ wide; females: 48-50 body rings, circa $95 \mathrm{~mm}$ long, 7.9-10 mm wide.

Color in living specimens very dark, darkest of all Aphistogoniulus species (Fig. 7B). Head, anal valves, subanal scale, legs and antenna bright red. Body rings almost completely brownish black. Metazonites latero-dorsally with a small orange field (Figs 1C, D), not reaching down to ozopore.

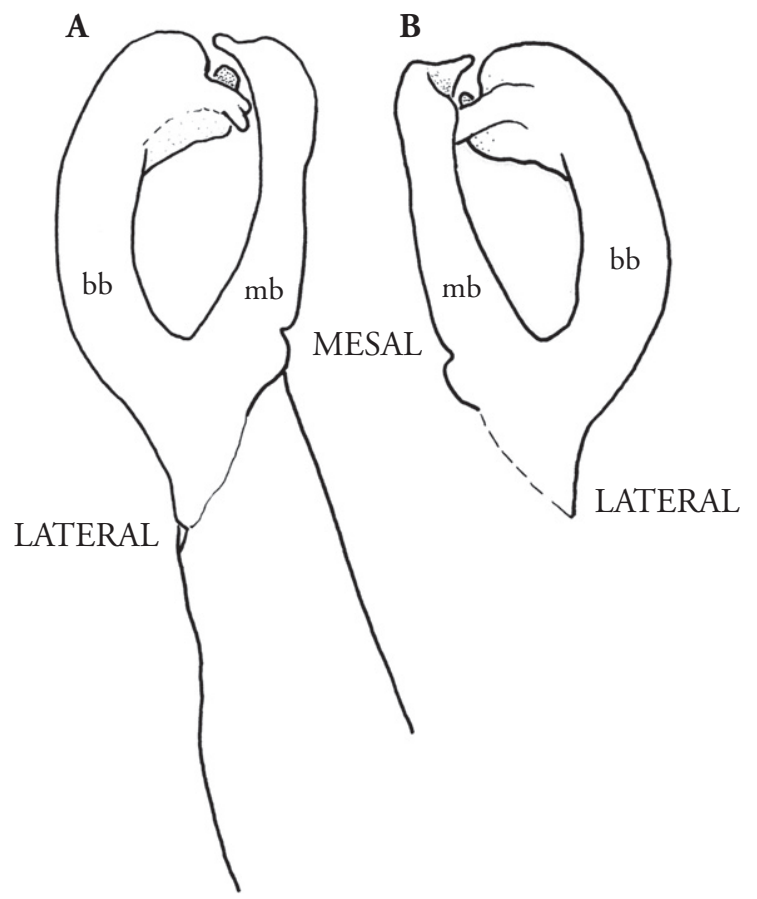

Figure 12. A. corallipes, lectotype (MNHN HB020), right posterior gonopods, A: oral view; B: anal view. Abbreviations: $\mathrm{bb}=$ basal branch; $\mathrm{mb}=$ main branch. Drawings not to scale. 

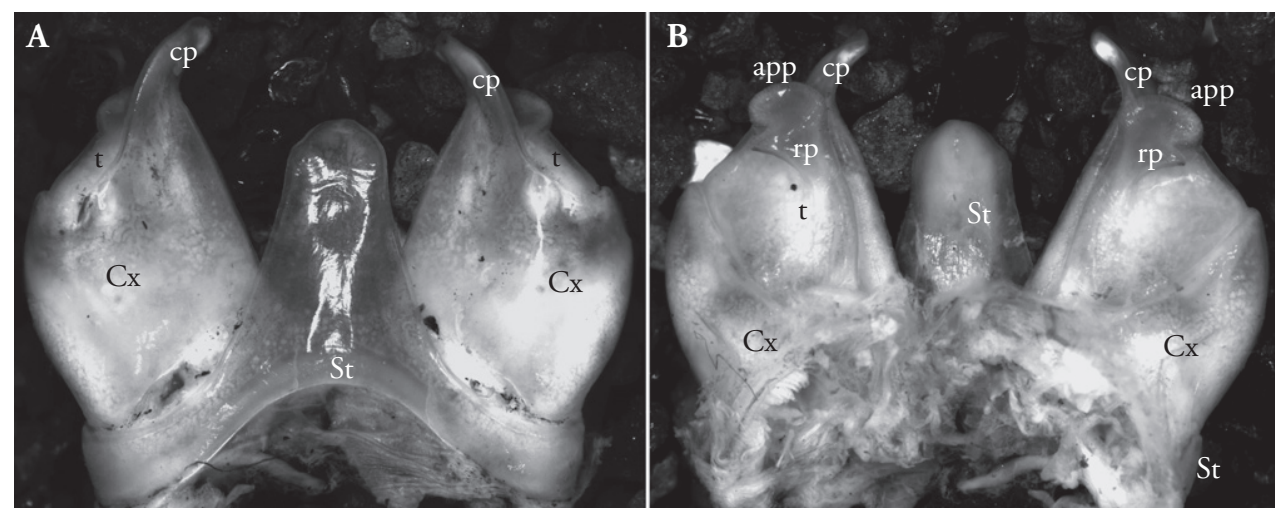

Figure 13. A. corallipes, anterior gonopods (FMMC), A: oral view; $\mathbf{B}$ : anal view. Abbreviations: app = appendage; $\mathrm{Cx}=$ coxite; $\mathrm{cp}=$ coxite process; $\mathrm{mb}=$ main branch; $\mathrm{rp}=$ retrorse process of appendage; $\mathrm{St}=$ sternite; $\mathrm{t}=$ telopodite. Figures not to scale.

Antenna of medium length, extending back to fifth body ring (Fig. 1C).

Anterior gonopod sternite elongated into single, well-rounded lobe (Fig. 13A). Coxite process very long, extending far beyond telopodite (Fig. 13A). Telopodite appendage weakly swollen, retrorse process sharp, projecting medially (Fig 13B).

Posterior gonopod telopodite branches forming 'O' (Fig. 12A). Tips of basal and main branches touching; main branch apically with slim prolongation, as wide and as long as main branch (Fig. 12B). Width of basal branch apically increasing, membranous fringe extending from tip along inner concave curvature of main branch (Figs 12A, B).

Intraspecific variation: the size of the type specimens collected close to Tolagnaro (Fort Dauphin) falls within the variation observed inside the Manantantely population.

Remarks: the specimens determined by Demange (1969) as A. corallipes are not conspecific with the lectotype, designated here. Those identified by Enghoff (1996) as Aphistogoniulus aff. corallipes are in fact $A$. cowani (see under this species). The type series of $A$. corallipes also included specimens of $A$. erythrocephalus.

Conservation and distribution: Aphistogoniulus corallipes has a very restricted distribution in South-Eastern Madagascar (Fig. 6). Specimens were collected by Alluaud in the surroundings of Fort Dauphin in 1901. In 2007, there was no remaining lowland rainforest vegetation surrounding Fort Dauphin except for the PR Manantantely, $5 \mathrm{~km}$ West of the city. Since different Aphistogoniulus species can be found in the Andohahela chain and in the few remaining lowland rainforest vestiges North of Fort Dauphin, $A$. corallipes is nowadays most likely restricted and endemic to the small PR Manantantely.

Aphistogoniulus sakalava (de Saussure \& Zehntner, 1897)

Spirobolus sakalava de Saussure \& Zehntner, 1897: pl. 11, fig. 46. Type data: female lectotype, designated herewith (MNHN HB053), examined.

Spirobolus (Trigoniulus) sakalava - de Saussure \& Zehntner 1902: 138, pl. 13, fig. 1. 
Aphistogoniulus sakalava - Jeekel 1971: 36; Enghoff 2003: 623 (lists species name).

Material examined: $1 \mathrm{~F}$

Lectotype (designated herewith): F, MNHN HB053, Madagascar, Forêt de Moramanga, $18^{\circ} 56^{\prime} 20.00^{\prime} \mathrm{S}, 48^{\circ} 13^{\prime} 40.00^{\prime \prime} \mathrm{E}$, coll. Catat, 1894 , det. H. de Saussure. The original description mentions two other immature specimens, which could not be located.

Diagnosis: males unknown! Female $87 \mathrm{~mm}$ long, $7.5 \mathrm{~mm}$, wide with 47 body rings. Head, antenna, legs and telson red. Mesozonites in dorsal half completely red. Red color not reaching down to ozopores. Dorsally no black band. Body rings in ventral half black. Metazonites ventrally and dorsally black (Fig. 7C). The low number of body rings, small size and the coloration pattern separate $A$. sakalava from all other known Aphistogoniulus species.

Description: Measurements: lectoype: 47 body rings, circa $87 \mathrm{~mm}$ long, $7.5 \mathrm{~mm}$ wide.

Color in living specimens believed to be this species unique (Fig. 7C). Head, antenna, legs and telson red. Mesozonites in dorsal half completely red; red coloration not reaching down to ozopores. Dorsally black band as found in other species absent. Ventral half of body rings black. Metazonites ventrally and dorsally black.

Antenna short, extending back to third body ring.

Male unknown.

Intraspecific variation: photographs of Aphistogoniulus specimens taken on localities close to the type locality such as Torotorofotsy (15 km NE of Moramanga) and Mantadia (12 km E of Moramanga) show specimens with 53 body rings and a color pattern similar to $A$. sakalava, except that the collum is completely red and the legs are golden. However, photographs taken at Andasibe of a specimen clearly identical in color with $A$. sakalava show a specimen with 48 body rings (Fig. 7C). This specimen was not collected. It is unclear if these photographs show two separate, sympatric Aphistogoniulus species, or only $A$. sakalava.

Conservation and distribution: $A$. sakalava is so far only known with certainty from the type locality, the forest of Moramanga. However, photographs taken in the forest of Andasibe show Aphistogoniulus specimens identical with the A. sakalava lectotype in size, number of body rings and color pattern. Aphistogoniulus sakalava individuals are currently the most common Aphistogoniulus species in the pet trade.

\section{Aphistogoniulus sanguineus Wesener, new species}

Material examined: $10 \mathrm{M}, 7 \mathrm{~F}, 1 \mathrm{imm}$.

Holotype: 1 M, CAS BLF 7024, Madagascar, Province Mahajanga, Réserve Spéciale Ambohijanahary, Forêt d'Ankazotsihitafototra, $35.2 \mathrm{~km} 312^{\circ} \mathrm{NW}$ Ambaravaranala, $1050 \mathrm{~m}$, montane rainforest, $18^{\circ} 16^{\prime} 00^{\prime \prime}$ S, 4524'24” E, coll. C. Griswold, B. Fisher et al., 13-17.i.2003.

Paratypes: 1 M, 3 F, 1 imm., CAS BLF 7014, same data as holotype. 
Other material examined: 1 M, 1 imm., FMMC '53', Madagascar, Province Antananarivo, RS d'Ambohitantely, $24 \mathrm{~km} \mathrm{NE}$ Ankazobe, disturbed transitional montane mossy forest, $1450 \mathrm{~m}, 18^{\circ} 10.1^{\prime} \mathrm{S}, 47^{\circ} 16.6^{\prime} \mathrm{E}$, coll. S. Goodman, 7-12.xii.1997, pitfall traps; 3 M, 4 F, FMMC '54', same data as previous; 1 M, FMMC no number, same data as previous; 2 M, FMMC 7890, same data as previous; 1 M, FMMC 7904, same data as previous.

Diagnosis: males up to $100 \mathrm{~mm}$ long, $8.9 \mathrm{~mm}$ wide with 48 or 49 body rings. Head, body rings 1-3 and telson completely blood-red, remaining body rings pitchblack. Posterior gonopod telopodite main branch with lateral membranous fringe strongly developed into erect process (Fig. 14C). Telopodite width increasing towards

A

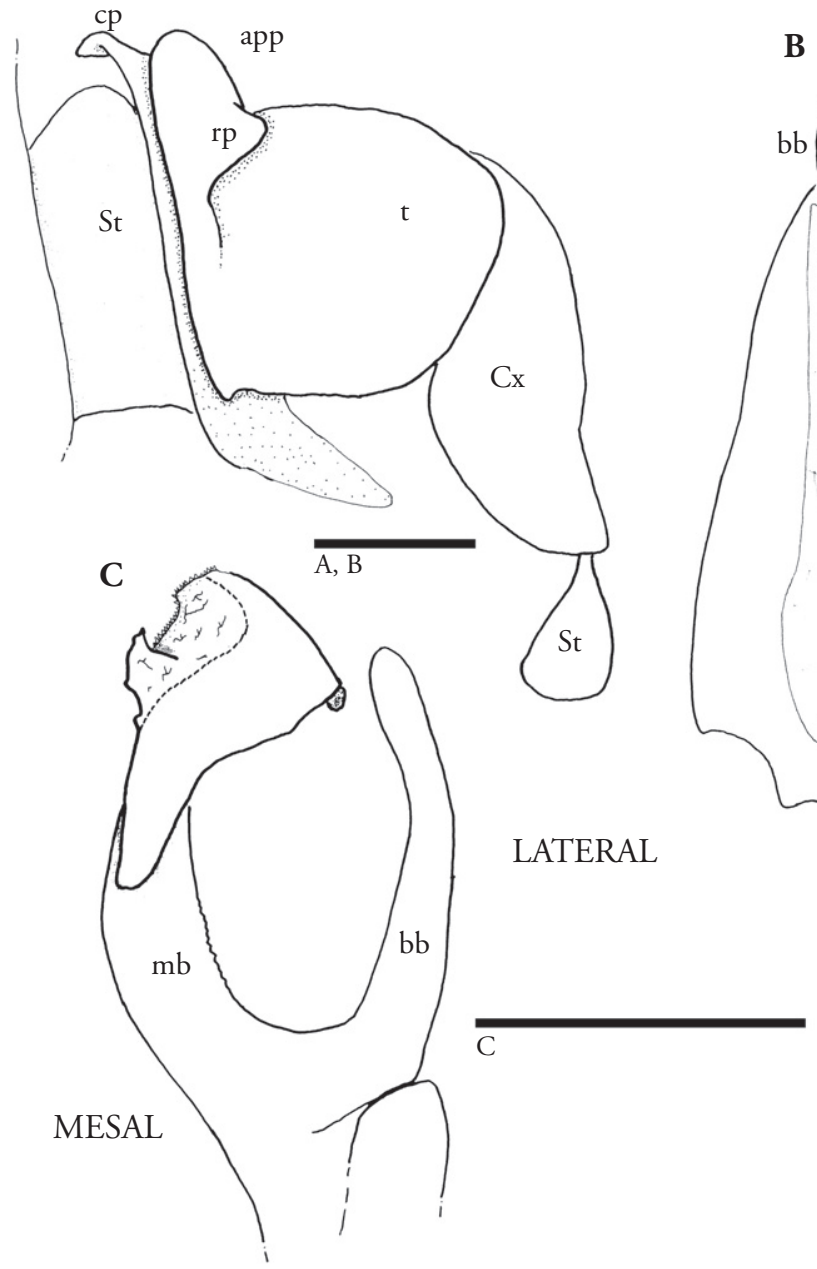

B

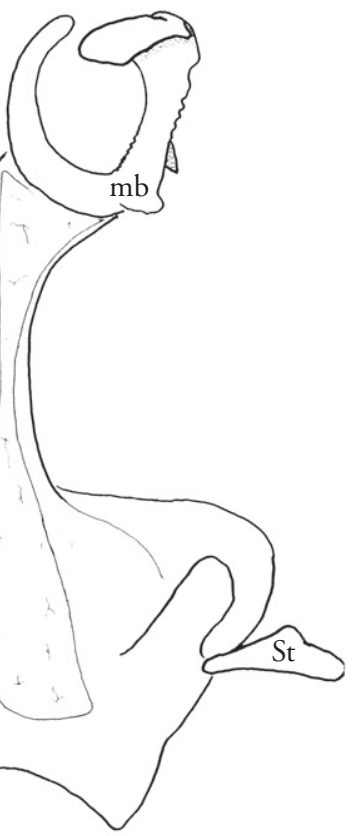

Figure 14. A. sanguineus n. sp., holotype (CAS), A: anterior gonopod, anal view; B: right posterior gonopod, anal view; $\mathbf{C}$ : right posterior gonopod, oral view. Abbreviations: app = appendage; $b \mathrm{~b}=$ basal branch; $\mathrm{Cx}=$ coxite; $\mathrm{cp}=$ coxite process; $\mathrm{mb}=$ main branch; $\mathrm{rp}=$ retrorse process of appendage; $\mathrm{St}=$ ster nite; $\mathrm{t}=$ telopodite. Scale bars $=1 \mathrm{~mm}$. 
apex (Fig. 14B). A lateral membranous fringe is only present in $A$. sanguineus and $A$. cowani. See $A$. cowani for a listing of the differences between both species.

Description: Measurements: males: 48 or 49 body rings, circa $100 \mathrm{~mm}$ long, $8.7-$ $8.9 \mathrm{~mm}$ wide; females: 48 body rings, circa $116 \mathrm{~mm}$ long, up to $10.9 \mathrm{~mm}$ wide.

Color in freshly preserved specimens with unique pattern. Head, legs, antenna, anal segment, collum, body rings two and three completely red, remaining rings black, mesozonite faded to grey in some preserved specimens (Fig. 1E).

Antenna of medium length, extending back to fifth body ring in males (Fig. 1F).

Anterior gonopod sternite elongated into single, well-rounded lobe (Fig. 14A). Coxite process long, extending beyond telopodite (Fig. 14A). Telopodite appendage weakly swollen. Retrorse process well-rounded, apically projecting (Fig. 14A).

Posterior gonopod telopodite branches forming 'O' (Fig. 14B). Tips of main and basal branch close, but not touching one another. Basal branch slim, but almost as long as main branch (Fig. 14C). Width of main branch apically increasing, laterally with strongly developed membranous fringe (Fig. 14C).

Intraspecific variation: females are present in two size classes; the smaller ones are $90 \mathrm{~mm}$ long and 9.0-9.6 mm wide. Both sexes show the same, unique color pattern. The female antenna extends only back to the third body ring (Fig. 1E). Species from the $1450 \mathrm{~m}$ elevation site are similar to those of the type series. There are minor differences in the posterior gonopods of specimens from the type locality at Ambohijanahary and those collected $200 \mathrm{~km}$ East in the mossy forest of Ambohitantely. These differences are viewed as intraspecific variation.

Conservation and distribution: A. sanguineus is known from the Ambohijanahary area. The RS Ambohijanahary is located at the Western slopes of the Malagasy high plateau (Fig. 6). The vegetation of Ambohijanahary includes one of the last vestiges of Malagasy subhumid forest. The specimens from Ambohitantely were collected in the mossy forest almost $200 \mathrm{~km}$ east of the type locality.

Derivatio nominis: sanguineus, adjective, (Latin, 'blood-colored') refers to the blood-red color of this species.

\section{Aphistogoniulus infernalis Wesener, new species}

Material examined: $22 \mathrm{M}, 5 \mathrm{~F}$

Holotype: 1 M, FMMC, Province Toliara, Sainte Luce, S8, 2446.520'S, 047 09.074'E, $28 \mathrm{~m}$, littoral forest on basaltic soil, coll. Wesener et al., 29.v.2007.

Paratypes: 4 M, 2 F, FMMC, same data as holotype; 1 M, 1 F, ZMH, same data as holotype; $1 \mathrm{M}$, ZMUC, same data as holotype.

Other material examined: $5 \mathrm{M}, 1 \mathrm{~F}, 1 \mathrm{imm}$., same data as holotype, University Antananarivo; $4 \mathrm{M}, 1 \mathrm{imm}$., PN Andohahela, Isaka-Ivondro Sud, $571 \mathrm{~m}$, rainforest, $24^{\circ} 46.302^{\prime}$ S, $46^{\circ} 51.699^{\prime} \mathrm{E}$, coll. Wesener et al., 12.vi.2007, University Antananarivo; 4 M, FMMC, same data as previous; 1 M, 1 F, FMMC, Andohahela, Isaka-Ivondro 
Nord, 668 m, rainforest, $24^{\circ} 44.185^{\prime}$ S, $46^{\circ} 51.607^{\prime} \mathrm{E}$, coll. Wesener et al., 12.vi.2007; 1 $\mathrm{M}$, same data as previous, University Antananarivo.

Diagnosis: males up to $125 \mathrm{~mm}$ long, $10.5 \mathrm{~mm}$ wide with $50-53$ body rings. Anterior gonopod retrorse process located apically on appendage (Fig. 15A). Posterior gonopod, main branch lacking membranous folds, some membranous fringes at apex (Fig. 15B). Main branch much slimmer and slightly shorter than basal branch. Basal branch basally very wide and of swollen appearance (Fig. 15C). Apex extended into much slimmer, tapering and curved tip. Basal branch mesally with single, larger sclerotized spine (Figs 15B, C). The shape of the posterior gonopods, especially the greatly enlarged and swollen basal branch, is unique inside Aphistogoniulus.

Description: Measurements: males: 50-53 body rings, circa 110-125 mm long, 8.1-10.5 mm wide. Females 48-53 rings, $128-136 \mathrm{~mm}$ long, $10.5-11.2 \mathrm{~mm}$ wide.

Color in living specimens on head anteriorly red, posteriorly dark-red to brown. Collum anteriorly towards head with two small red spots, remaining part of collum

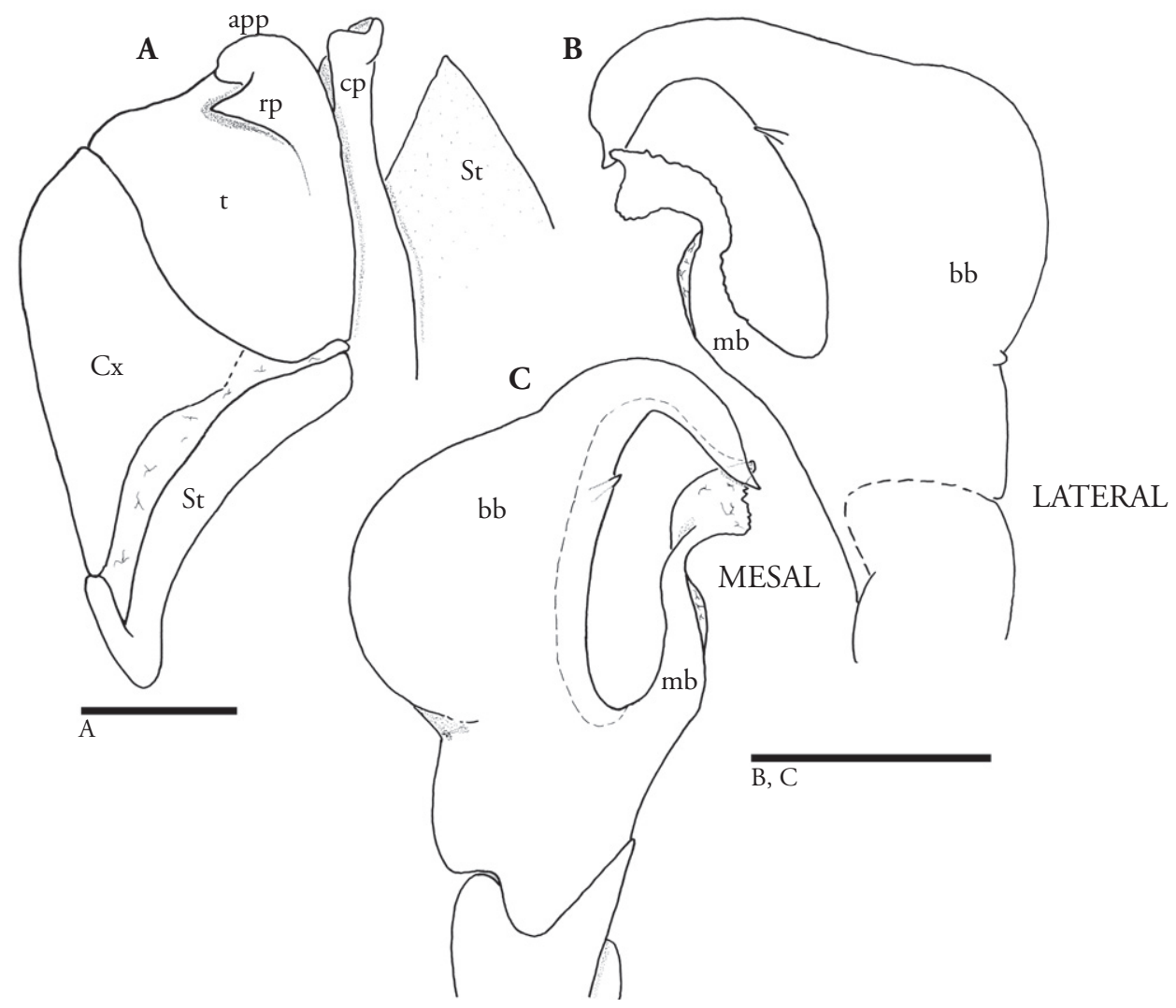

Figure 15. A. infernalis n. sp., holotype (FMMC), A: anterior gonopod, anal view; B: left posterior gonopod, oral view; C: left posterior gonopod, anal view. Abbreviations: app = appendage; bb = basal branch; $\mathrm{Cx}=$ coxite; $\mathrm{cp}=$ coxite process; $\mathrm{mb}=$ main branch; $\mathrm{rp}=$ retrorse process of appendage; $\mathrm{St}=$ sternite; $\mathrm{t}=$ telopodite. 
dark-red to brown (Fig. 7E). Body rings dorsally with row of large black spots, one spot on each metazonite. Mesozonites dorsolaterally blood-red, reaching down to ozopores. Mesozonites laterally and ventrally dark-red to brown, ozopore highlighted by darker spot. Metazonites all black. Antenna and legs red, telson dark red (Fig. 7E).

Antenna long, extending back to sixth body ring.

Anterior gonopod sternite triangular with sharp tip (Fig. 15A). Coxite process elongated, as long as or slightly longer than telopodite. Telopodite appendage only weakly swollen. Large, sharp-edged retrorse process projecting medially (Fig. 15A).

Posterior gonopod telopodite branches forming 'O' (Fig. 15B). Tips of main and basal branch touching and slightly overlapping (Fig. 15B). Main branch at mesal margin as well as apically with membranous folds (Fig. 15C). Main branch apically three times as wide as basally. Main branch much slimmer and slightly shorter than basal branch. Basal branch very wide and of swollen appearance (Fig. 15C). Apex extended into much slimmer, tapering and curved tip. Basal branch mesally with single, larger sclerotized spine (Fig. 15C).

Intraspecific variation: specimens from Isaka-Ivondro Sud are slightly smaller than those from Sainte Luce (width 8.1-8.5 mm instead of 8.6-9.0 $\mathrm{mm}$ in the type series). Surprisingly, specimens from Isaka-Ivondro Nord are slightly larger than those from Sainte Luce and Isaka-Ivondro Sud (width $8.8 \mathrm{~mm}$ ). All three specimens from Isaka-Ivondro Nord have 53 body rings, while specimens from Sainte Luce and IsakaIvondro Sud have 48-51 rings.

Conservation and distribution: so far, $A$. infernalis is known from the Andohahela mountain chain in the Isaka-Ivondro corridor and from the last parcel of littoral forest on lateritic soil (latosol) in Sainte Luce (Fig. 6). The littoral rainforest at the type locality in Sainte Luce is tiny $(<100 \mathrm{ha})$ and now completely isolated from other natural forests by a vast corridor of disturbed, species-poor pseudosteppe grassland (which represent a hostile environment for soil arthropods). Recent cleared patches and manioc plantations inside the Sainte Luce littoral forest fragment show that this unique forest is under great anthropogenic pressure. It is unlikely that the last lateritic littoral forest fragment will survive the next ten years (Bollen \& Donati 2006).

Derivatio nominis: infernalis, adjective, (Latin, masculine, 'from hell') refers to the striking blood-red and pitch-black color pattern of the species.

\section{Aphistogoniulus diabolicus Wesener, new species}

\section{Material examined: $4 \mathrm{M}$}

Holotype: 1 M, FMMC 6169, Province Fianarantsoa, PN Midousy, NE slope Mt. Papangomalong Andrauorena R., $3.5 \mathrm{~km} \mathrm{SW} \mathrm{Befotaka,} \mathrm{montane} \mathrm{rainforest,} 1250$ m, 2350.3'S, 46 $57.5^{\prime}$ E, coll. S. M. Goodman, pitfall trap, 2-7.xi.2003.

Paratypes: 3 M, FMMC 6169, same data as holotype.

Diagnosis: males up to $120 \mathrm{~mm}$ long, $8.1 \mathrm{~mm}$ wide with 53 or 54 body rings. Anterior gonopod appendage wide but compressed, retrorse process located apically 
on swollen appendage (Fig. 16B). Tips of posterior gonopod main and basal branch close to, but never touching one another (Fig. 16C). Width of posterior gonopod basal branch not strongly increasing before apex (Fig. 16D). No mesal membranous fold at main branch of posterior gonopods (Fig. 16C). The shape of the posterior gonopods, is similar to those in $A$. aridus $\mathbf{n}$. sp. and $A$. vampyrus n. sp. A. diabolicus is the only species lacking a lateral membranous fold on the main branch of the posterior gonopods (Fig. 16C). The anterior gonopod appendage is less strongly developed than in other Aphistogoniulus species (Fig. 16B).

Description: Measurements: males: 53 or 54 body rings, circa $110-120 \mathrm{~mm}$ long, 8.0-8.1 mm wide.

Color of head, legs and telson in freshly conserved specimen red. Collum and body rings laterally black, dorsally blood-red, except for black spot on metazona, visible as black stripe in uncurled specimen. If the specimen curls into a spiral (defence behaviour), more blood-red color becomes visible dorsally.

Antenna long, extending back to fifth body ring.

Anterior gonopod sternite triangular with well-rounded tip (Fig. 16A). Coxite process elongated, longer than telopodite (Fig. 16A). Telopodite appendage only weakly swollen. Sharp-edged retrorse process starting to project apically (Fig. 16B).

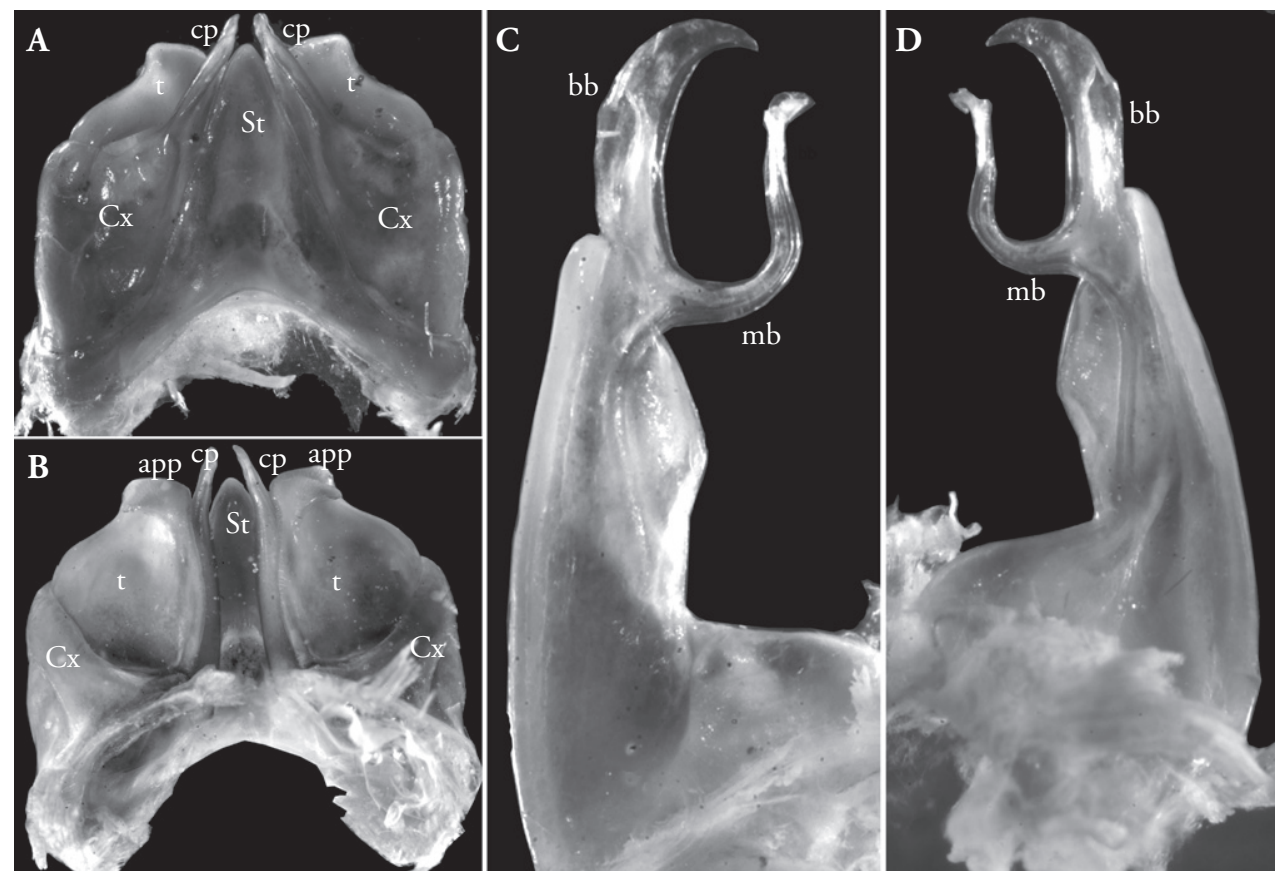

Figure 16. A. diabolicus n. sp., holotype (FMMC 6169), montage images, A: anterior gonopod, oral view; B: anterior gonopod, anal view; C: posterior gonopod, oral view; D: posterior gonopod, anal view. Abbreviations: $\mathrm{app}=$ appendage; $\mathrm{bb}=$ basal branch; $\mathrm{Cx}=$ coxite; $\mathrm{cp}=$ coxite process; $\mathrm{mb}=$ main branch; $\mathrm{rp}=$ retrorse process of appendage; $\mathrm{St}=$ sternite; $\mathrm{t}=$ telopodite. 
Posterior gonopod telopodite branches forming an 'O' (Fig. 16C). Tips of main and basal branch close to, but not touching one another. Main branch only apically with membranous bi-lobical folds (Fig. 16D). Main branch half as wide as but shorter than basal branch. Basal branch tapering, apex sharp (Figs 16C, D).

Conservation and distribution: $A$. diabolicus is currently known only from the Midousy National Park (Fig. 6).

Derivatio nominis: diabolicus, adjective (Latin, 'characteristic of the devil'), refers to the horn-like retrorse process on the anterior gonopod.

\section{Aphistogoniulus aridus Wesener, new species}

\section{Material examined: $2 \mathrm{M}$}

Holotype: 1 M, CAS BLF 5241, Madagascar, Province Toliara, Forêt de Mahavelo, Isantoria River, 110 m, spiny forest thicket, $24^{\circ} 45^{\prime} 30^{\prime \prime S}$, 46 $9^{\circ} 26^{\prime \prime} \mathrm{E}$, coll. Fisher, Griswold et al. 28.i.-01.ii.2002.

Paratype: 1 M, CAS BLF 5241, same data as holotype.

Diagnosis: males up to $104 \mathrm{~mm}$ long, $8.5 \mathrm{~mm}$ wide with 53 body rings. Head red (Fig. 1G). Antenna conspicuously short, only extending back to fourth body ring (Fig. 1G). Male prefemora 3-5 only in this species with shallow invaginations (Fig. 17A). Anterior gonopod appendage wide (Fig. 17B). Tips of posterior gonopod main and basal branch close to, but never touching one another (Fig. 17C). Width of posterior gonopod basal branch not strongly increasing before apex (Fig. 18A). The shape of the posterior gonopods, with membranous folds apically and mesally on the main branch and a basal branch completely lacking membranous fringes mirrors closely those of $A$. vampyrus $\mathbf{n}$. sp. $A$. aridus differs however from $A$. vampyrus $\mathbf{n}$. sp. in the presence of invaginations of the male prefemur 3-5 (absent in A. vampyrus), the red head (posteriorly black in $A$. vampyrus), dorsal black stripe (row of black spots in $A$. vampyrus), a much longer anterior gonopod coxite process (not longer than telopodite in $A$. vampyrus), and a much shorter antenna (extending back to 6th body in $A$. vampyrus).

Description: Measurements: holotype: 53 body rings, circa $104 \mathrm{~mm}$ long, $8.5 \mathrm{~mm}$ wide.

Color of head, legs, telson, antenna in freshly preserved specimens red. Collum medially and ventrally red, laterally and dorsally pitch-black (Fig. 1G). Body rings dorsally with black stripe, mesozonite dorsolaterally red, laterally black and ventrally red. Posterior margin of metazonite always black. Ozopores accentuated by large black spot.

Antenna short, extending back to fourth body ring (Fig. 1G). Male prefemur 3-5 conspicuously invaginated medially (Fig. 17A).

Anterior gonopod sternite triangular. Coxite process long, extending beyond telopodite (Fig. 17B). Telopodite appendage only weakly swollen. Well-rounded retrorse process starting to project apically (Fig 17B).

Posterior gonopod telopodite branches forming an 'O' (Fig. 18A). Tips of main and basal branch close to but not touching one another (Fig. 17C). Main branch at mesal 

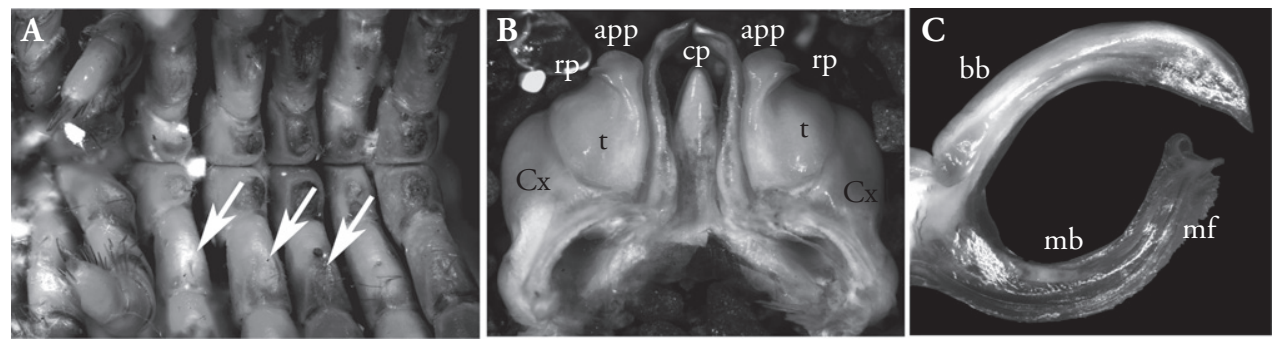

Figure 17. A aridus n. sp., holotype (CAS BLF 5241), A: male legs 1-7, ventral view, arrows mark invaginations on male prefemur 3-5; B: anterior gonopods, anal view; $\mathbf{C}$ : posterior gonopod, oral view. Abbreviations: $\mathrm{app}=$ appendage; $\mathrm{bb}=$ basal branch; $\mathrm{Cx}=$ coxite $\mathrm{cp}=$ coxite process; $\mathrm{mb}=$ main branch; $\mathrm{mf}$ $=$ membranous fold $; \mathrm{rp}=$ retrorse process of appendage; $\mathrm{St}=$ sternite; $\mathrm{t}=$ telopodite. Figures not to scale.

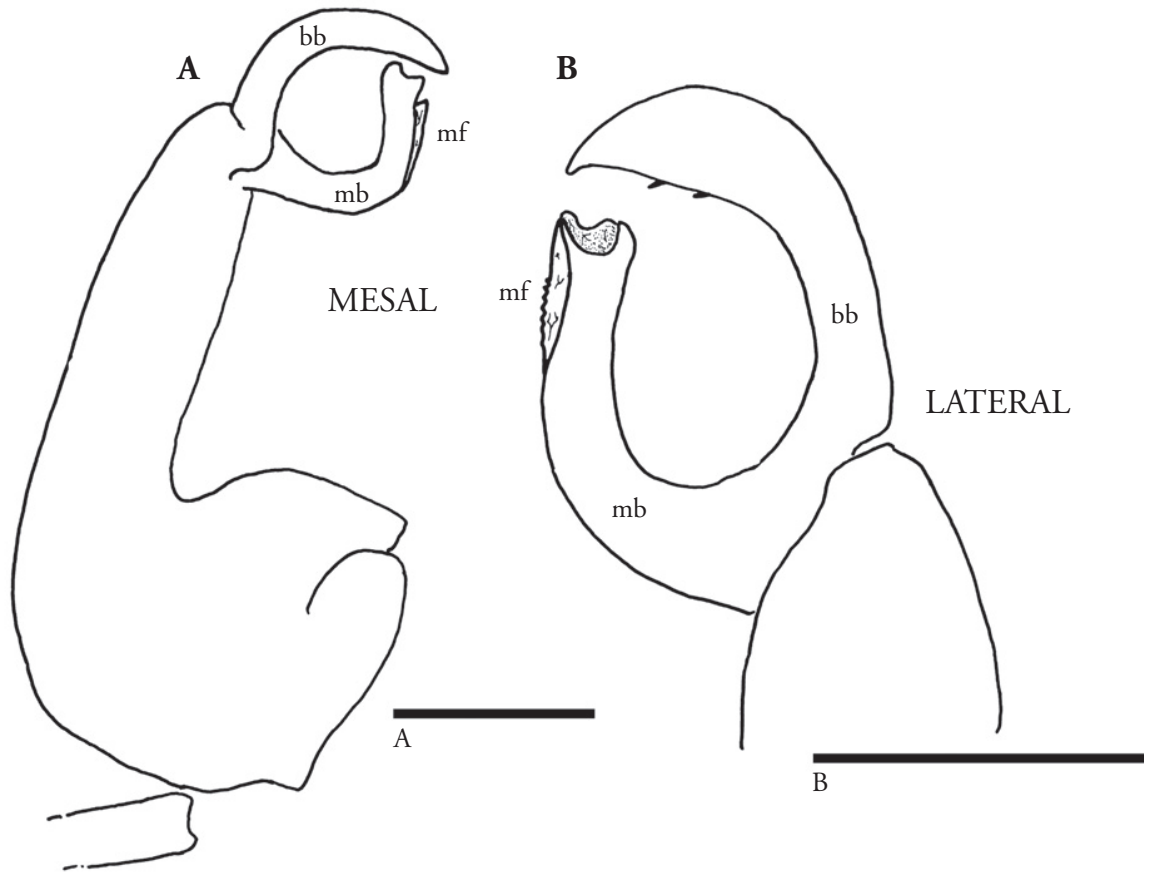

Figure 18. A. aridus n. sp., holotype (CAS BLF 5241), right posterior gonopods, A: anal view; B: oral view. Abbreviations: $\mathrm{bb}=$ basal branch; $\mathrm{mb}=$ main branch; $\mathrm{mf}=$ membranous fold. Scale bars $=1 \mathrm{~mm}$.

margin and apically with membranous folds, tip bi-lobed (Fig. 18B). Main branch as wide as and only slightly shorter than basal branch. Basal branch becoming slightly thicker before tapering towards apex (Figs 17C, 18A); mesally with two minute sclerotized spines (Fig. 18B).

Conservation and distribution: thus far, $A$. aridus is only known from the spiny forest of Mahavelo (Fig. 6). It is the only species of Aphistogoniulus recorded from a dry forest ecosystem. 
Derivatio nominis: aridus, adjective (Latin, 'to be dry'), refers to the distribution inside the dry spiny forest.

\section{Aphistogoniulus vampyrus Wesener, new species}

Material examined: $41 \mathrm{M}, 14 \mathrm{~F}$

Holotype: 1 M, CAS BLF 5015, Madagascar, Province Toliara, PN Andohahela, Col du Sedro, $3.8 \mathrm{~km} 113^{\circ}$ ESE Mahamavo, $37.6 \mathrm{~km} 341^{\circ} \mathrm{NNW}, 900 \mathrm{~m}$, montane rainforest, $24^{\circ} 45^{\prime} 50^{\prime}$ S, 46 45'6”E, coll. Fisher, Griswold et al, 21-25.I.2002.

Paratypes: 2 M, 4 F, 3 imm., CAS BLF 5015, same data as holotype.

Other material examined: 2 M, FMMC 5365, Province Toliara, RNI d' Andohahela, $13.5 \mathrm{~km} \mathrm{NE} \mathrm{Eminiminy,} \mathrm{camp} \mathrm{\# 3,} 1200 \mathrm{~m}$, montane rainforest, 24³5.0'S, 4644.1'E, coll. S. Goodman, pitfall trap, 1-17.xi.1995; 8 specimens, FMMC 5366, same collection data as previous; 1 M, 1 F, FMMC 5375, RNI Andohahela, parcel 1, $810 \mathrm{~m}$, montane rainforest, 24³5.6'S, 4644.3'S, coll. S. Goodman et al, 28.x.-7. xi.1995, pitfall traps; 2 M, 2 F, FMMC 5387, RNI Andohahela, parcel 1, 1500 m, montane rainforest, 2434.2'S, 4643.9'S, coll. S. Goodman et al, 17-27.xi.1995; 14 M, 2 F, FMMC 5389, same collection data as previous; 3 M, 2 F, FMMC 5391, same data as previous; 6 M, FMMC 5392, same data as previous; 10 M, 2 F, FMMC 5414, RNI Andohahela, parcel I, NW Eminiminy, $1500 \mathrm{~m}$, montane rainforest, $24^{\circ} 32.2^{\prime} \mathrm{S}$, 4643.9'E, coll. S. Goodman, 17-27.xi.1995; 1 F, FMMC 8189, same data as previous.

Diagnosis: males up to $106 \mathrm{~mm}$ long, $7.9 \mathrm{~mm}$ wide with 49-50 body rings. Head frontally red, posteriorly black (Fig. $1 \mathrm{H})$. Antenna extending back to sixth body ring (Fig. 1H). Anterior gonopod appendage wide (Fig. 19B). Tips of posterior gonopod main and basal branch close to, but never touching one another (Fig. 19C). Width of posterior gonopod basal branch not strongly increasing before apex (Fig. 20). The shape of the posterior gonopods closely mirrors that of $A$. aridus. For distinction between the very similar $A$. aridus n. sp. and $A$. vampyrus n. sp. see above.

Description: Measurements: males: 49 or 50 body rings, circa $98-106 \mathrm{~mm}$ long, 7.3-7.9 mm wide. Females 49, 106-115 mm long, 9.5-9.9 wide.

Color of head in freshly conserved specimens frontally red, posteriorly black. Collum towards head red, posteriorly with two red spots (Fig. 1H). Body rings dorsally with row of large black spots, one spot located on metazonite of each ring. Rings dorsolaterally red, laterally black and ventrally mesozonites red, metazonites black. Telson, legs and antenna red. Ozopores already located in black area, not marked by black spots.

Antenna long, extending back to sixth body ring (Fig. 1H).

Anterior gonopod sternite triangular with sharp tip (Fig. 19A). Coxite process elongated, as long or slightly shorter than telopodite (Fig. 19A). Telopodite appendage only weakly swollen, sharp-edged retrorse process starting to project medially (Fig. 19B).

Posterior gonopod telopodite branches forming an 'O' (Fig. 19C). Tips of main and basal branch close but not touching one another. Main branch at mesal margin 

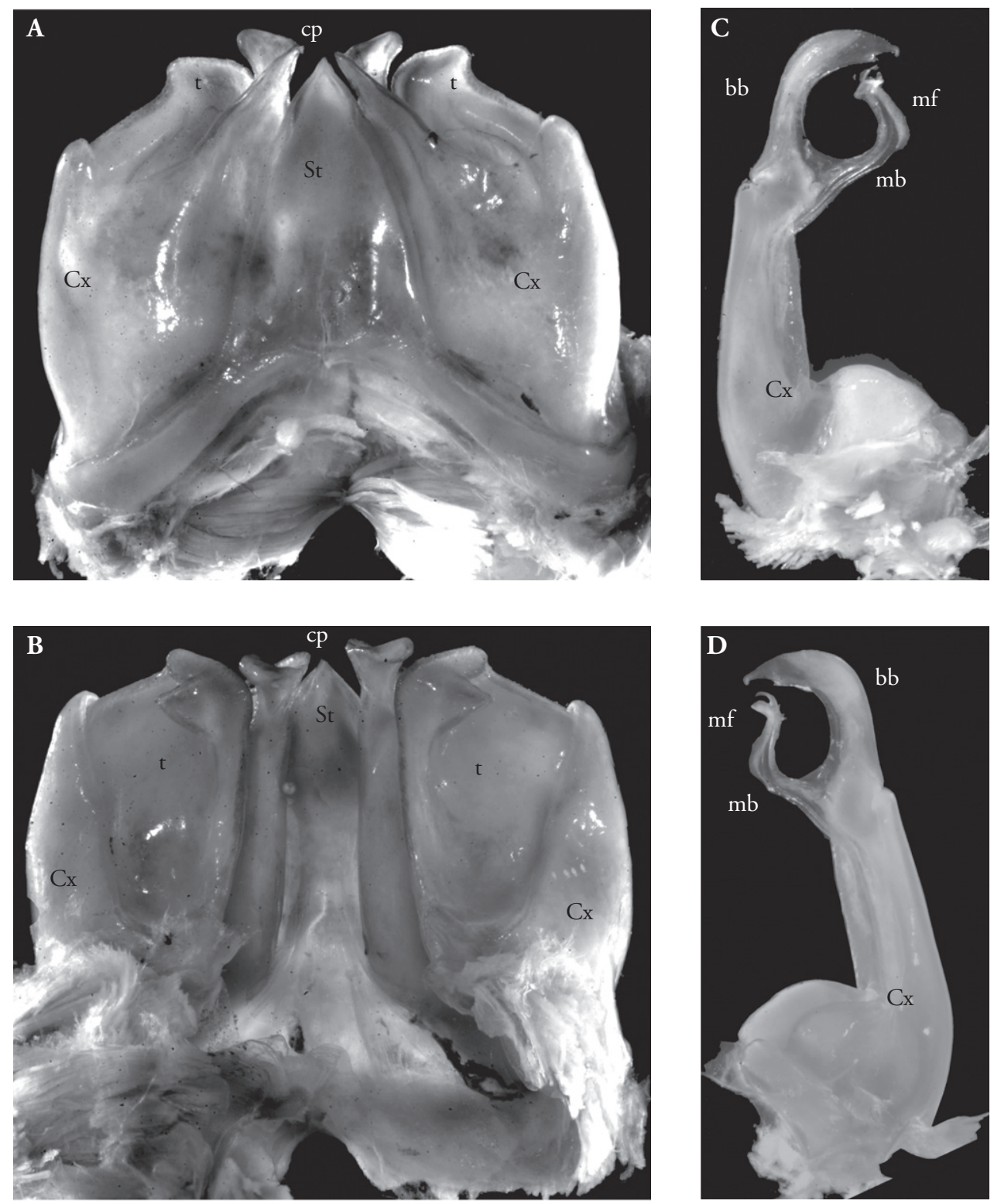

Figure 19. A. vampyrus n. sp. (FMMC 5366), A: anterior gonopods, oral view; B: anterior gonopods, anal view; C: right posterior gonopod, oral view; $\mathbf{D}$ : right posterior gonopod, anal view. Abbreviations: app $=$ appendage $; \mathrm{bb}=$ basal branch $\mathrm{Cx}=$ coxite $\mathrm{cp}=$ coxite process $\mathrm{mb}=$ main branch $; \mathrm{mf}=$ membranous fold; $r p=$ retrorse process of appendage; $\mathrm{St}=$ sternite; $\mathrm{t}=$ telopodite. Figures not to scale.

as well as apically with membranous folds, tip bi-lobed (Fig. 19D). Main branch as wide as and only slightly shorter than basal branch. Width of basal branch increasing before strongly tapering towards its apex (Figs 19C, D; 20), mesally with single, larger sclerotized spine (Fig. 20). 


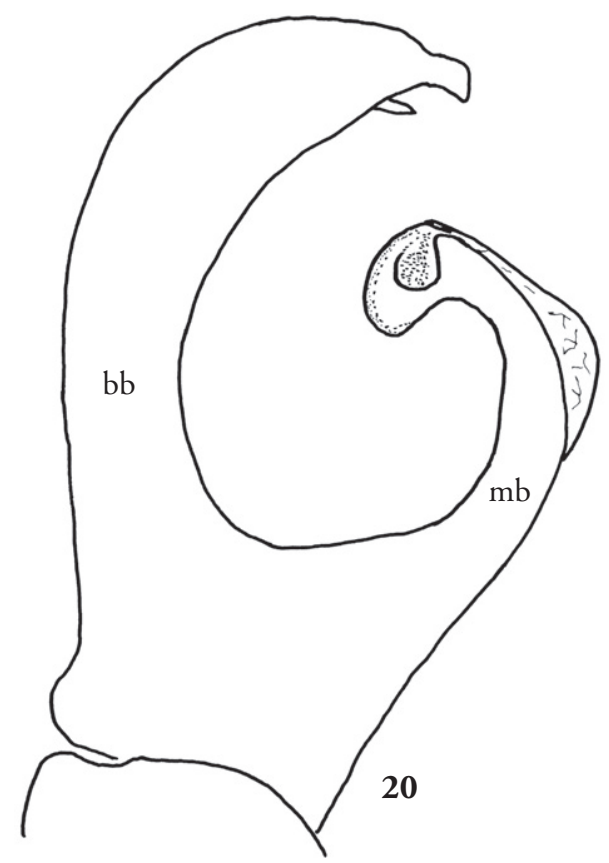

Figure 20. A. vampyrus n. sp., holotype (CAS BLF 5015), left posterior gonopod, oral view. Abbreviations: $\mathrm{bb}=$ basal branch; $\mathrm{mb}=$ main branch.

Intraspecific variation: females are present in two size classes, the smaller ones are $100 \mathrm{~mm}$ long and $9.5 \mathrm{~mm}$ wide, while the larger ones reach up to $115 \mathrm{~mm}$ long and more than $10 \mathrm{~mm}$ wide.

Conservation and distribution: currently, $A$. vampyrus is only known from the Andohahela mountain chain North of the Isaka-Ivondro corridor (Fig. 6). A. vampyrus is obviously replaced by the brighter colored $A$. infernalis in the Isaka-Ivondro and the Eastern lowland forest of Sainte Luce.

Derivatio nominis: vampyrus, adjective (Latinized form of the Slavic word 'vampyr" = vampire), refers to the general dark and blood-red color pattern of the species.

\section{Discussion}

The closest relative of the genus Aphistogoniulus has so far not been identified. A species of Aphistogoniulus (A. erythrocephalus) was included in the only phylogenetic analysis of Pachybolidae published so far (Wesener et al. 2008) but this analysis provided very little resolution. Aphistogoniulus is quite unique among the described Trigoniulidea genera, because of the strongly elongated posterior gonopod coxite and a much smaller telopodite. Two undescribed genera from Madagascar share those characteristics with Aphistogoniulus. Molecular studies could help to illuminate the relationships of Aphistogoniulus to other pachybolids. 
The eye-catching blood-red/pitch-black color pattern (Figs 7A-E) is certainly an interesting aspect of Aphistogoniulus. This pattern is most likely correlated with the exposed, often arboreal way of life discovered in many Aphistogoniulus species. A. corallipes, which was found in a more reclusive habitat (leaf litter), has a much darker coloration than, for example, $A$. infernalis, where the specimens were found often climbing on trees or resting in epiphytes. The color pattern is with high probability aposematic - many species of Spirobolida are known to be able to excrete a malodorous defensefluid containing benzoquinones from the openings of their defense glands (Eisner et al. 1978). A strong-smelling, yellow fluid was observed in A. corallipes and A. infernalis by TW, however, the composition of this secretion is unknown. This pattern is similar to one discovered in the South African pachybolid genus Centrobolus where brightly colored species are found in much more exposed situations than those without strong colors (Lawrence 1967). The highest species diversity in Aphistogoniulus has been found in the Southeast of Madagascar (Fig. 6). The only Aphistogoniulus species adapted to a dry environment, $A$. aridus n. sp., was collected in this region. One reason for this pattern can be found in the relatively large amount of inventory work conducted in Southeastern Madagascar (Goodman 1999). Furthermore, this Malagasy region has a strong rainfall gradient (Battistini 1972, Donque 1972), the boundaries between Eastern rainforest and Southern spiny forest are therefore quite sharp (Goodman 1999). Species boundaries seem to be very sharp, too. A. infernalis was found in the lowland forest North of Tolagnaro (Fort Dauphin) as well as in the Isaka-Ivondro corridor of the Andohahela National Park. The related species A. vampyrus was found in Andohahela just $10 \mathrm{~km}$ Northwest of Isaka-Ivondro, and A. corallipes just $10 \mathrm{~km}$ Northwest of Tolagnaro (Fig. 6). The fact that, even in a genus consisting of such large and conspicuous species, five out of eight species collected during recent inventory work were undescribed, highlights how little we know about the millipede fauna of Madagascar.

\section{Acknowledgements}

This article is part of a dissertation titled "Biodiversity, Evolution, Biogeography and Ecological Specialization of Malagasy Diplopoda" conducted by TW at the FriedrichWilhelms University of Bonn. Special thanks go the curators and collection managers who placed the material at our disposal: Charles Griswold and Darrel Ubick (CAS), James Boone (FMNH), Jean-Jacques Geoffroy and Jean-Paul Mauriès (MNHN) and G. Owen Evans (British Museum). The paper is part of the Accords de Collaboration between the Université d'Antananarivo (Dept. Biologie Animale and Anthropologie et Biologie Evolutive), QIT Madagascar Minerals and Hamburg University. The support by Olga Ramilijaona and D. Rakotondravony is gratefully acknowledged. During fieldwork QIT Madagascar provided logistics support (arranged by Jean-Baptiste Ramanamanjato). Collecting permits were arranged by Dr. Olga Ramilijaona (Departement de Biologie Animale, Université d'Antananarivo). Special thanks go to the Direction des Eaux et Forêts, Antananarivo for arranging collecting and export per- 
mits. The first author conducted the fieldwork together with Kai Schütte (University of Hamburg) and with priceless help by the local assistant Refaly Ernest and numerous local guides. Photographs of living animals were provided by David R. Parks, Harald Schütz, Kai Schütte, and Arne Friedrich. Betty Strack (FMNH) advised on the SEM. Our special thanks go to Sergei Golovatch and an anonymous reviewer, which comments greatly improved the quality of the paper. Mike Jorgensen (FMNH) kindly improved the English of this article. This study was supported by the "Studienstiftung des Deutschen Volkes" with a monthly grant (TW), by PEET (NSF grant DEB 97-12438 and 05-29715), by the European Commission's (FP 6) Integrated Infrastructure Initiative program SYNTHESYS (FR-TAF-1166 and DK-TAF-1167) and is part of the DFG-project WA530/37-1 "Biodiversity and Biogeography of Malagasy Diplopoda".

\section{References}

Attems, C. (1910) Myriopoden von Madagaskar, den Comoren und den Inseln Ostafrikas. - In: Voeltzkow (ed.): Reise in Ostafrika in den Jahren 1903-1905: Wissenschaftliche Ergebnisse 3: 73-115.

Battistini, R. (1972) Madagascar relief and main types of landscape. - In: Battistini, R. \& Richard-Vindard, G. (eds) Biogeography and Ecology in Madagascar. Monographiae Biologicae 21. The Hague, 1-27.

Bollen, A. \& Donati, G. (2006) Conservation status of the littoral forest of south-eastern Madagascar: a review. - Oryx 40 (1): 57-66.

Brolemann, H.-W. (1922) Liste des Myriapodes de L`Académie Malgache, De Tananarive. Bulletin de la Société Zoologique de France, Paris 47: 223-240.

Butler, A.G. (1882) On new Spirostrepti. - The Annals and Magazine of Natural History 5 (9): 328-330.

de Saussure, H. \& Zehntner, L. (1897) Atlas de l'histoire naturelle des Myriapodes. - In: Grandidier (ed.) Histoire physique, naturelle et politique de Madagascar 27 (53): plates 1-12.

de Saussure, H. \& Zehntner, L. (1902) Myriapodes de Madagascar. - In: Grandidier (ed.) Histoire physique, naturelle et politique de Madagascar 27 (53): i-viii, 1-356, pl. 13-15.

Donque, G. (1972) The climatology of Madagascar. - In: Battistini, R. \& Richard-Vindard, G. (eds) Biogeography and Ecology in Madagascar. Monographiae Biologicae 21. The Hague, $87-145$.

Eisner, T., Alsop, D., Hicks, K. \& Meinwald, J. (1978) Defensive secretions of millipeds. - In:

Bettini, S. (ed.) Arthropod venoms. Handbook of experimental pharmacology. Springer, Berlin, Heidelberg, New York 48: 41-72.

Enghoff, H. (1996) Millipedes (Diplopoda) from the eastern slopes of the Réserve Naturelle Intégrale d'Andringitra, Madagascar. - Fieldiana Zoology 85: 90-92.

Enghoff, H. (2003) Diplopoda, Millipedes. - In: S. M. Goodman \& J. P. Benstead (Eds.) The Natural History of Madagascar. University of Chicago Press, Chicago, 617-627.

Goodman, S.M. (1999) A floral and faunal inventory of the Réserve Naturelle Intégrale d'Andohahela, Madagascar. - Fieldiana Zoology 94: 1-297. 
Jeekel, C.A.W. 1971. Notes on the genus Aphistogoniulus Silvestri (Diplopoda, Spirobolida, Trigoniulidea). - Bulletin Zoölogisch Museum, Universiteit van Amsterdam 2 (6): 33-42. Lawrence, R.F. (1967) The Spiroboloidea (Diplopoda) of the eastern half of southern Africa. Annals of the Natal Museum 18: 607-646, 1 pl.

Lowry II, P. P., Ganzhorn, J.U., Schatz, G.E. \& Sommer, S. (2001) The biodiversity of Madagascar: one of the world's hottest hotspots on its way out. - Oryx 35 (4): 346-348.

Mesibov, R., Taylor, R.J. \& Brereton, R.N. (1995) Relative efficiency of pitfall trapping and handcollecting from plots for sampling of millipedes. - Biodiversity and Conservation 4: 429-439.

Myers, N., Mittermeier, R.A., Mittermeier, C.G., Fonseca, G.A.B. \& Kent, J. (2000) Biodiversity hotspots for conservation priorities. - Nature 403: 853-858.

Pocock, R.I. (1893) Upon the identity of some of the types of Diplopoda contained in the collection of the British Museum, together with descriptions of some new species of exotic Iulidae. - The Annals and Magazine of Natural History 6 (11): 248-254.

Sierwald, P. \& Bond, J. E. (2007) Current status of the myriapod class Diplopoda (millipedes): taxonomic diversity and phylogeny. - Annual Reviews of Entomology 52: 401-420.

Silvestri, F. (1897a) Neue Diplopoden. - Abhandlungen und Berichte des Königlichen Zoologischen und anthropologisch-ethnographischen Museums zu Dresden 6 (9): 1-23.

Silvestri, F. (1897b) Systema Diplopodum. - Annali del Museo Civico di Storia Naturale di Genova 38: 651-653.

Wesener, T. \& Sierwald, P. (2005) The Giant Pill-Millipedes of Madagascar: Revision of the Genus Sphaeromimus, with a review of the morphological terminology (Diplopoda, Sphaerotheriida, Sphaerotheriidae). - Proceedings of the California Academy of Sciences 56 (29): 557-599.

Wesener, T., Enghoff, H. \& Wägele, J.-W. (2008) Pachybolini - a tribe of giant Afrotropical millipedes: arguments for monophyly and the description of a new genus from Madagascar (Diplopoda: Spirobolida: Pachybolidae). - Invertebrate Systematics 22: 37-53.

Wesener, T. \& Wägele, J.-W. (2008) The giant pill-millipedes of Madagascar: revision of the genus Zoosphaerium (Myriapoda, Diplopoda, Sphaerotheriida). - Zoosystema 30 (1): 1-85. 